\title{
EL YACIMIENTO DE MAS CASTELLAR DE PONTÓS Y EL COMERCIO DEL CEREAL IBÉRICO EN LA ZONA DE EMPORION Y RHODE (SS. IV-II A. C.)
}

\author{
POR \\ A. M. ${ }^{a}$ ADROHER, E. PONS i BRUN y J. RUIZ DE ARBULO \\ Universidad de Granada, Servei d'Investigacions Arqueològiques \\ de Girona y Universitat de Lleida'
}

\section{RESUMEN}

Se presentan nuevos hallazgos en el yacimiento que permiten identificar en su última fase (siglos IV-II a. C.) un posible santuario de Deméter y Core rodeado de un campo de silos. Apuntan en este sentido el hallazgo de una estructura de culto incluyendo un altar helenístico en mármol pentélico y un gran depósito votivo localizado en el interior de un silo. Este depósito permite identificar el significado ritual de otros hallazgos anteriores en el interior de silos.

\section{SUMMARY}

This paper deals with some recents findings which suggest that in the last phase (IV-II B. C.) the site of Mas Castellà (Pontós) was a sanctuary dedicated to Deméter and Kore which was surrounder by a field of silos. The findings of a cultual structure with an Hellenistic altar made of Penthelic marble and of a big votive deposit within a silo point to this possibility. This deposit allowed us to understand the ritual meaning of some other findings within silos which were made in former excavations.

'A.A. Dep. de Prehistoria y Arqueología, Univ. de Granada, 18071, Granada t (958) 24361 1; E.P.B. Servei d'Investigacions Arqueologiques, Pedret, 95. 17007, Girona t. (972) 204637; J.RdA. Sec. de Arqueología, Fac. de Lletres, Univ. de Lleida, 25003 Lleida t. (973) 702028. 


\section{EL YACIMIENTO Y SU INVESTIGACIÓN (Fig. 1)}

El yacimiento de Mas Castellar de Pontós está situado en la depresión altoempordanesa, sobre una pequeña elevación ( 140 m.s.n.m.) limitada al norte y noroeste por el cauce de la riera Alguema (afluente del río Manol) con cortados de 25 a $55 \mathrm{~m}$. de altura y descendiendo suavemente hacia el sur en dirección al cauce del Fluvià, a $2 \mathrm{~km}$. de distancia. Se trata por tanto de una colina abierta, con defensas naturales y una amplia visibilidad de $25 \mathrm{~km}$. a la redonda. El terreno está cubierto hoy en dia por trabajos agricolas y un manto boscoso de encinas. Un paisaje semejante en lineas generales al que presentaria en época antigua, cuando el yacimiento se situaba en las sierras de poca altura que limitaban la marisma litoral que cubria toda la costa del golfo de Rosas. Su posición, a unos $20 \mathrm{~km}$. de distancia de Emporion y de Rhode, equidistante de ambas ciudades siguiendo los cauces fluviales que aseguraban la comunicación a través de la marisma, convierten este yacimiento, destacado centro geopolítico, en un importante documento para el estudio de la iberización en el Ampurdán.

La existencia del yacimiento, comunicada por el propietario de los terrenos, motivó en el año 1966 una inspección de J. Maluquer y M. Oliva y la divulgación de su existencia ${ }^{2}$, pero no seria hasta los años 1975-1977 cuando el Centre d'Investigations Arqueològiques de Girona, bajo la dirección de A. Martín, realizase las primeras excavaciones. A partir de estos trabajos, el lugar fue definido como un "campo de silos»: un yacimiento de época ibérica, con abundante presencia de importaciones griegas, caracterizado por una gran concentración de silos sin que se apreciara su relación con estructuras de hábitat ${ }^{3}$. A. Martín destacaría el enorme volumen de almacenamiento de estos silos ${ }^{4}$, publicando diversos materiales o hallazgos significativos en conjuntos de colmatación con presencia de campaniense A: un conjunto de terracotas con cabeza de Deméter aparecidas en el relleno del silo $28^{5}$, un «hogar en fosa» en el silo 26 , aparición de otro hogar singular definido como "hogar ritual», hallazgo de un ostracon discoidal con cuatro líneas en alfabeto ibérico en el silo 25, etc. ${ }^{6}$ En trabajos más recientes, A. Martín ha señalado la presencia de materiales massaliotas, llegados en su opinión por intermedio de Rhode?

\footnotetext{
${ }^{2}$ Oliva, M.A.: Nuevo importante yacimiento prerromano en el Ampurdán: el poblado de Puig Castellar (Pontós, Gerona), Pyrenae, 4, 1968, 171.

${ }^{3}$ Martín, A. : El yacimiento indígena pre-romano de Mas Castellà de Pontós, XV Congreso Nacional de Arqueologia (Lugo 1977), 1979, 677-690.

${ }^{4}$ Martín, A.: Memoria de la segunda campaña de excavaciones en el yacimiento de Mas Castellà de Pontós, Revista de Girona, 78, 1977, 55: «estos silos tienen una capacidad entre 6 y 8 m. cúbicos y algunos mayor aún. Un metro cúbico de trigo o de avena pesa unos $660 \mathrm{~kg}$. Con las modernas técnicas de producción, $1 \mathrm{Ha}$ de terreno aquí da unos $1800 \mathrm{~kg}$. de trigo, por lo que puede calcularse que cada uno de estos silos puede contener como mínimo la producción de $2 \mathrm{Ha}$...» Añadiremos únicamente a esta observación que los silos presentan dimensiones variables. Los hallados en la parte superior de la colina son de tamaño inferior a los excavados por Martín en la terraza media.

${ }^{5}$ Martín, A. y Llavaneras, N.: Un conjunt de timateris amb representació de Deméter procedent del Mas Castellà de Pontos, Cypsela, 3, 1980, 153-161.

${ }^{\circ}$ Martín 1979, op. cit. n. 3

7 Martín, A.: Aportacions de les excavacions de Roses a l'estudi del comerç massaliota a l'Alt Empordà en els segles IV-III a.C., Cypsela, 4, 1982, 113-122; Ruiz de Arbulo, infra, señala no obstante la imposibilidad de distinguir en los siglos IV-III a.C. los comercios emporitano y rodio.
} 


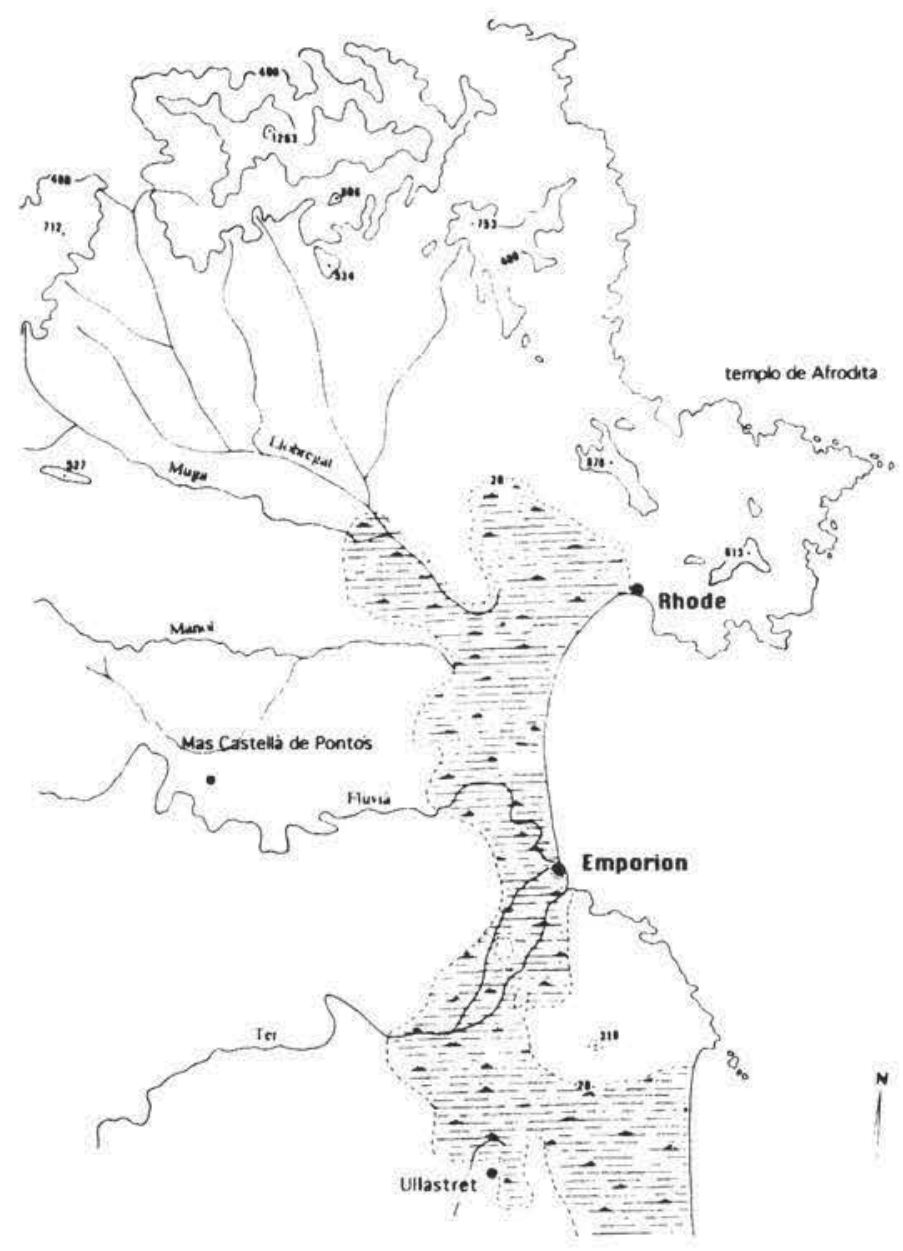

Figura 1.- Plano topográfico del Ampurdán en época antigua, con situación de los yacimientos citados en el texto y restitución aproximada de la marisma (según J. Ruiz Arbulo).

Una primera restitución esquemática del paisaje en la Antigüedad y la inserción en el mismo del yacimiento ha sido planteada por Ruiz de Arbulo ${ }^{8}$, valorando éste como el principal testimonio del comercio del cereal ibérico que habría ocasionado el auge económico de Emporion y Rhode en el siglo IV a. C. "Junto al oppidum de Ullastret se trata de un punto clave para entender las relaciones entre los iberos indicetes y los habitantes de las colonias del golfo.

\footnotetext{
${ }^{8}$ Ruiz de Arbulo, J.: Emporion y Rhode, dos asentamientos portuarios en el golfo de Rosas, Arqueologia espacial, 4, Teruel, 1984, 128-132 y fig. 4.

" Ruiz de Arbulo ibid.; Ruiz de Arbulo, J.: Emporion. Ciudad y territorio. Algunas reflexiones preliminares, Revista d'Arqueologia de Ponent, 2, 1992, 59-74. En este último trabajo se rebate la opinión de Domínguez, A.: La función económica de la ciudad griega de Emporion, VI Col.loqui Int. d'Arqueologia de Puigcerdà (1984), Puigcerda, 1986, 193-199 que identificaba erróneamente los silos con fosas de agua para el trabajo del lino. Ver también una breve referencia al yacimiento en Sanmartí, E.: Les influences méditerranéennes au nord-est de la Catalogne à l'époque archaique et la reponse indigene, I Focei dall'Anatolia all'Oceano, PdP, 37, 1982, 281-303.
} 


\section{LAS NUEVAS INVESTIGACIONES Y SUS RESULTADOS (Fig. 2)}

En 1990, la investigación del yacimiento ha sido reemprendida por el CIA de Girona, bajo la dirección de E. Pons y A. Adroher, a través de una campana intensiva de prospección fotográfica, electromagnética y edafológica, continuada por realización de catas estratigráficas en los lugares oportunos ${ }^{10}$. Los importantes hallazgos alcanzados en la campaña de 1992 de cara a la definición y análisis del yacimiento " nos mueven a presentar un avance de los mismos de forma inmediata en colaboración con J. Ruiz de Arbulo.

Estos resultados se concentran en dos aspectos fundamentales:

1. Identificación de una primera fase de ocupación correspondiente a un oppidum ibérico amurallado destruido a fines del siglo $\mathrm{V}$-inicios del siglo IV a. C. (sondeo 3 ).

2. Documentación parcial de un edificio con dependencias (sondeo 1), abandonado en la primera mitad del siglo II a. C. y que definimos como parte de un edificio de culto por la presencia de un altar monolítico de mármol importado.

3. Hallazgo en la plataforma superior del yacimiento de un depósito votivo en el interior de un silo (núm. 101), igualmente datado en la primera mitad del siglo II a. C. (sondeo 4). Sus caracteristicas permiten entender igualmente como ofrendas votivas los hallazgos anteriores realizados por A. Martín («hogar ritual», «hogar en fosa» del silo 26, ostrakon ibérico, terracotas de Deméter, etc.).

Aunque sin evidencias epigráficas, los ritos atestiguados permitirian plantear la hipótesis de un santuario dedicado a las grandes diosas: Deméter y Core-Perséfone. La presencia de este santuario presidiendo un campo de silos sería un documento de excepción para lograr entender la relación entre íberos y griegos en el comercio cerealístico de los siglos IV/II a. C.: la concentración de los excedentes en un mercado neutral protegido por el carácter sacro de la divinidad.

Se trataría, pues, de un santuario empórico, cuyo papel como elemento de comercio y aculturación en la dinámica colonial ha sido ya bien estudiado en numerosos lugares. Al mismo tiempo, su situación interior, equidistante de Emporion y Rhode, permite estudiar su relación con unos territorios cuyas caracteristicas de momento desconocemos casi totalmente.

Las excavaciones de 1992 han documentado las fases correspondientes al abandono del yacimiento a mediados del siglo 11 a. C. Esta fecha no es causal, sino que coincide con la

10 Tabernero, E., Vallejo, R. y Pons, E.: Indicadores analíticos de suelos como método de prospección: el yacimiento de Mas Castellar, Pontós, VIII Reunion Nacional sobre Cuaternario (Valencia 1991), en prensa; Adroher et alii (Equip de Pontós): La campanya de 1991 a Mas Castellà-Pontós: un exemple de prospecció arqueològica, Primeres Jornades d'Arqueologia a les comarques gironines (Sant Feliu de Guixols 1992). Pons \& Adroher et alii (Equip de Pontós): Mas Castellar-Pontós: resultats de les campanyes 1990-1992, Annals de l'Institut d'Estudis Empordanesos, 26. (en prensa).

"La documentación exhaustiva se encuentra recogida en los informes de excavación entregados al Servei d'Arqueologia de la Generalitat. Queremos mencionar como responsables de excavación en la campaña de 1992 a X. Barturen, R. Borreda, F. Contreras, J. M. García y E. Tabernero. Estudios especializados: C. Aguer y A. Cusó (restauración), N. Carulla y J. Aurell (geomorfología), R. Vallejo (sedimentología), R. Buxó y D. Canal (carpología), M. Ros (antracología), S. Casellas y M. Saña (fauna), B. Agustí (antropologia), A. Adroher, A. Marti y M. J. Fernández (ceramología) y Lluis Sant (topografia). Recordamos igualmente la participación entusiasta de un buen número de estudiantes de las Universidades Central y Autónoma de Barcelona, Tarragona, Valencia y Madrid. 

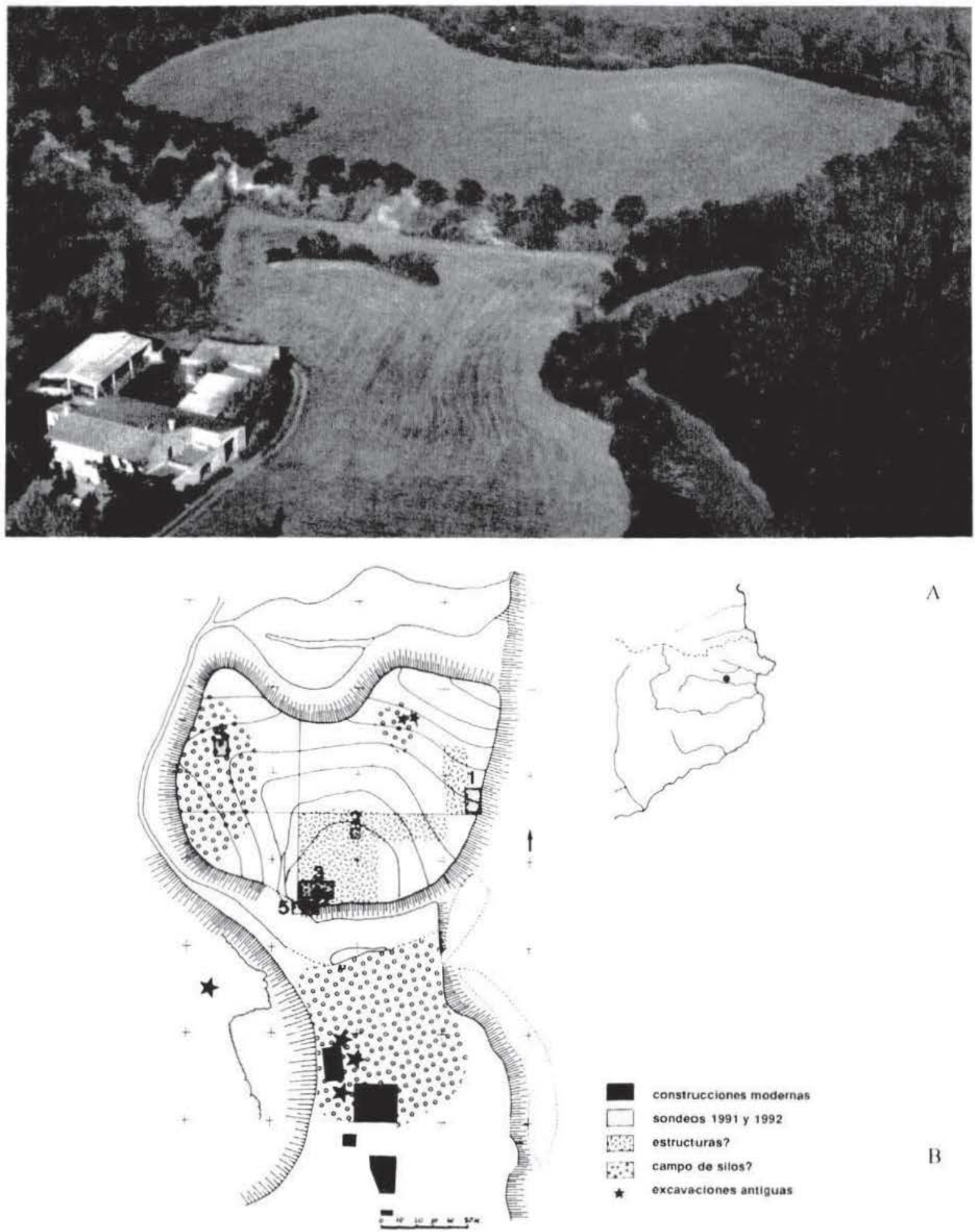

$\Lambda$

construcciones modernas

sondeos 1991 y 1992

estructuras?

campo de silos?

excavaciones antiguas

Figura 2.-Pontós. Planta general y sectores de excavacion. A. vista aérea del yacimiento y entorno hacia el norte. B, plano esquemático del Camp de Dalt con los sondeos efectuados en relación a las prospecciones. 
romanización efectiva del territorio emporitano y por tanto con la transformación de la situación social y económica que había motivado su existencia.

En este primer trabajo intentaremos fundamentalmente explicar esta última fase de la vida del yacimiento, interpretando las características del culto y su funcionamiento económico y politico. Examinaremos en primer lugar las evidencias documentadas.

\section{EL. EDIFICIO DE LA ZONA 1 (Fig. 3)}

La excavación ha delimitado, por debajo del nivel superficial, los restos arrasados de un edificio de varias habitaciones, con niveles de abandono y derrumbe de muros conservados sobre las pavimentaciones. Los limites exactos del edificio son todavia desconocidos en espera de la ampliación de la excavación en la próxima campaña de 1993. De momento se dibuja una planta rectangular en torno a una gran estancia central (1) rodeada por diversas cámaras $(2,3,4,5)$, sin que todavía puedan definirse con seguridad las circulaciones.

Los zócalos de los muros están realizados con material lítico heterogéneo (travertinos, areniscas, calcáreas, etc.) de tamaños desiguales calzados en ocasiones con ayuda de fragmentos anfóricos. Las estancias tienen suelos de tierra batida y guijarros dispersos con excepción de la sala 5, provista de un pavimento de cal (SL 27) que asciende en los laterales rebocando los muros. En la estancia central 1 aparece en un lateral una basa circular de arenisca correspondiente a un apoyo de columna (BS 13) alineada con uno de los muros.

Por encima de los pavimentos se extienden niveles de abandono con abundantes restos materiales y faunisticos. En la estancia central 1, las UEs 126 y 108 presentan restos faunísticos en conexión y la UE 132 la apariencia de un vertedero cerámico. Lo mismo ocurre en el nivel 129 que cubria el pavimento de cal de la estancia 5, con presencia de un molino y restos abundantes de cerámica, algo de fauna y metales. Las características del material de estos estratos son homogéneas: campaniense $\mathrm{A}$, ánforas grecoitálicas, púnicas y punicoebusitanas como importaciones, cerámica común ibérica pintada, gris de la costa catalana, ánfora ibérica y cerámica de cocina a mano, junto a algunos fragmentos áticos, massaliotas y del taller de Rosas como material residual. Un contexto situable por tanto en la primera mitad del siglo II a. C.

El análisis de la fauna recogida en estos niveles sobre el suelo de la estancia 1 muestra como elemento destacable la presencia mayoritaria de perro - canis familiaris - (202 restos, $85,2 \%, 5$ animales) seguido a gran distancia de buey - bos taurus - ( 11 restos, 4,6\%, 2 animales), oveja/cabra - ovis aries/capra hircus - (10 restos, $4,1 \%, 1$ animal), caballo - equus sp.- ( 7 restos, 2,9\%, 1 animal), cerdo - sus domesticus - (7 restos, 2,9\%, 1 animal).

En la estancia 3 aparecen en un lateral los restos de un hogar (LL 28) asociado a un pavimento de tierra batida (SL 36) y, sobre el mismo, un nivel de abandono (131) que presenta, junto al habitual conjunto cerámico, el hallazgo espectacular de un ara de mármol blanco fragmentada. La lista de materiales es la siguiente:

- Cerámica ática: 1 borde.

- Barniz negro, taller de Rosas: 1 fragmento.

- Campaniense A: 1 borde, 4 inf.

- Gris de la costa catalana: 2 bordes, 5 inf. 

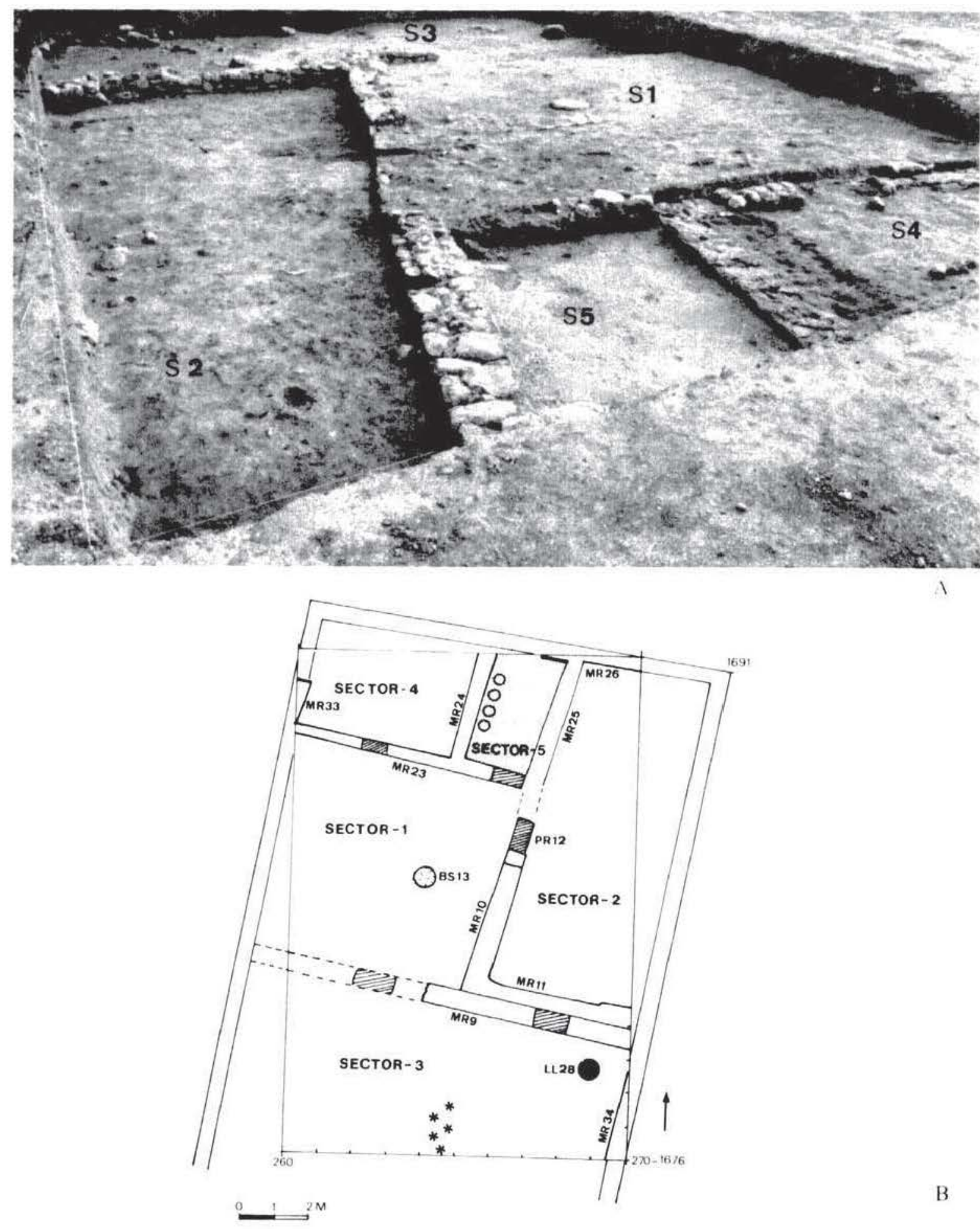

Figura 3. Edificio de la zona I. A, vista hacia el sur. B, plano hipotético en relación a los hallazgos. Se indica la numeración de los sectores y los principales contextos estratigráficos. Los asteriscos señalan los fragmentos del ara. 
- Común ibérica: 5 bordes, 127 inf.

- Mortero itálico: 2 bordes, 5 inf.

- Ánfora ibérica: 1 borde.

- Ánfora grecoitálica: 3 bordes, 5 asas, 83 inf.

- Ánfora púnica del Mediterráneo central: 2 inf.

- Cerámica a mano: 2 bordes, 3 decor., 19 inf.

- Discos (recortados de cer. ib.): 1.

- Fusayolas: 1.

- Hierro: 2 clavos.

- Bronce: 2 fragmentos.

- Moneda: unidad de bronce de Ebusus (3.06 gr., 18 mm., 12 h.), Campo 1976, núm. 17, c. $214-190$ a. C.

- Mármol: 27 fragmentos correspondientes a un ara (estudiada más adelante).

- Fauna: 52 fragmentos.

- Restos humanos: fragmentos de cuerpo derecho de mandíbula humana perteneciente a un adulto por encima de los veinticinco años, probablemente de sexo masculino.

\section{LOS SILOS DE LA ZONA 4 (Figs. 4,5 y 6 )}

Una cata de $8 \times 10 \mathrm{~m}$. en la zona 4 proporcionó bajo el nivel superficial la aparición del suelo natural, compuesto por un conglomerado detrítico con inclusión de areniscas en el que se abrían una serie de fosas circulares con rellenos antrópicos que hemos definido como fosassilos, procediéndose a la excavación completa de tres (SJ 100, 101 y 102). Los silos 100 y 102 contenian respectivamente cerámicas a mano $(100)$ y un contexto cerámico datable por copas Cástulo (102) cuya cronología se aleja, pues, del tema que ahora nos ocupa. Nos detendremos en la descripción del relleno del silo 101 .

- SJ 101

Se trata de una fosa circular de $1,44 \times 1,70 \mathrm{~m}$. de diámetro y una profundidad de $1,40 \mathrm{~m}$. correspondiente a un silo de $2,691 \mathrm{Tm}$. de capacidad. Su relleno, de excepcional riqueza, aparece en diversas capas que describimos por orden de sedimentación:

UE 418. Relleno del fondo de la fosa, con superficie horizontal, conteniendo fragmentos del reboque y pared de la fosa junto a fragmentos cerámicos, constructivos y carbones. Entre el material, señalar la presencia de cuatro piezas discoidales recortadas de ánforas púnicas e ibéricas.

UE 419. Sobre el suelo horizontal formado por el relleno 418 aparece, en posición centrada, una capa cenicienta circular de carbones minúsculos, correspondientes a pinus sylvestris y quercus ilex-coccifera.

UE 417. Cubriendo los carbones se extiende una capa heterogénea, con restos de las paredes de la fosa, abundante fauna y como materiales:

- Hierro: dos clavos.

- Bronce: un anzuelo, botón y anilla. 


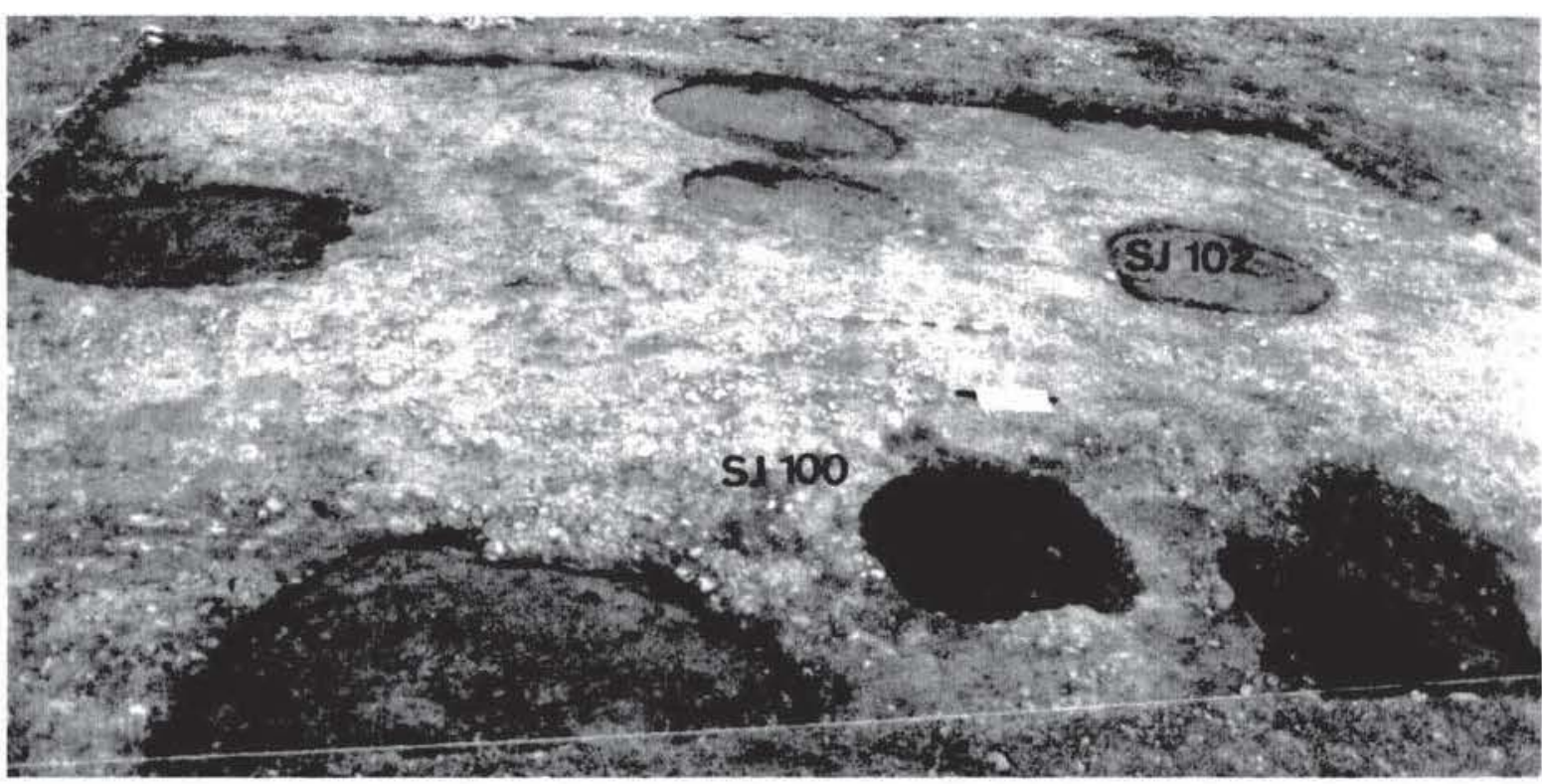

Figura 4. Aspecto de los silos de la zona 4.

A

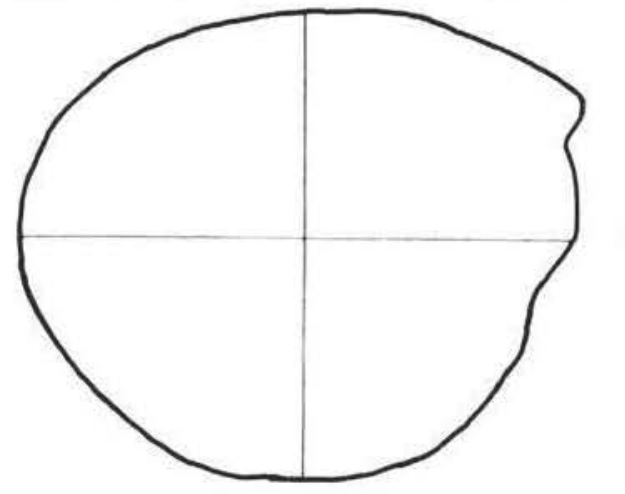

$1 \mathrm{M}$

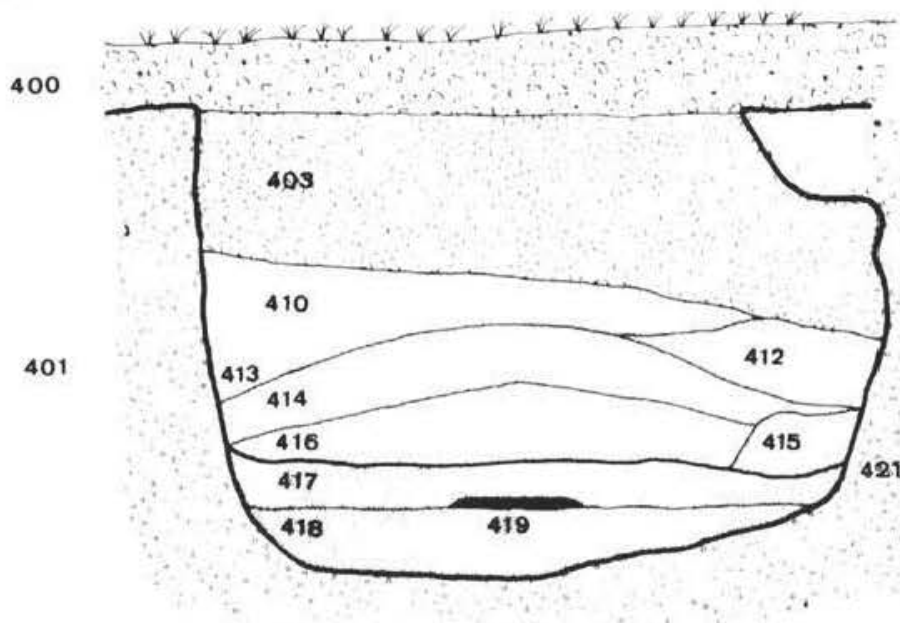

Figura 5.- Estratigrafia del silo 101: UE403, primer relleno; UE410-416, depósito; UE417, relleno secundario; UE418, último relleno antiguo; UE419, hogar. E. 3:100. 

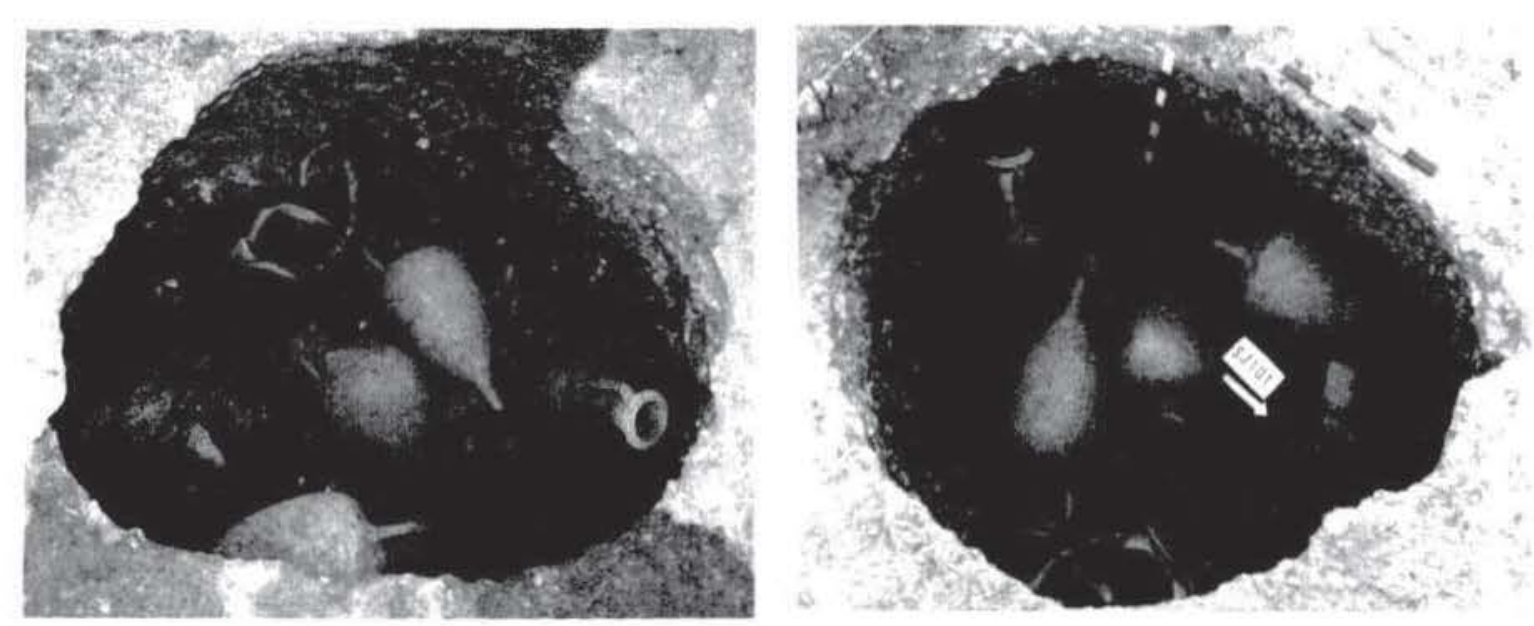

Figura 6. I:I deposito del silo 101 durante la excavacion.

Coroplastia: cabecita femenina de terracota (estudiada más adelante).

- Fusayolas: una.

- Discos ceramicos: dos piezas (en cerámica iberica y en ánfora itálica).

- Barniz negro. Taller Rosas: 1 informe.

Gris de la costa catalana: 4 bordes, 7 informes.

- Cerámica iberica: 10 bordes, 83 informes.

- Cerámica a mano: 4 bordes, 39 informes.

- Anfora púnica: 6 informes.

UE 416-410. Por encima de este nivel se extiende un relleno homogéneo (dividido cautelarmente durante la excavación en 6 niveles) caracterizado por la presencia de materiales integros, junto a fragmentos de adobes, carbones y restos más escasos de fauna. El inventario de los materiales es el siguiente:

- Barniz negro. Taller de Rosas: un cuenco Lamb. 27 completo.

- Campaniense A: un plato de pescado Lamb. 23; un cuenco Lamb. 27.

- Ánfora grecoitálica: ocho ánforas enteras, una con marca griega $\mathrm{H}$ y grafito latino inciso en la espalda $M A R(C O) R U L I O$.

- Ánfora ibérica: cuatro ánforas enteras.

- Cerámica ibérica: un cálato pintado y asas trenzadas de estilo Fontscaldes; un ascos (piezas enteras).

- Ungüentarios: un ejemplar.

- Morteros: un ejemplar.

- Discos: veinte discos recortados en cerámica.

Lógicamente añadiremos a esta lista un abundante conjunto de fragmentos que incluyen cerámica ática y de Rosas, ánfora púnica (2 fragmentos), común y ánfora ibérica (106 frag- 
mentos), gris de la costa catalana, cerámica a mano, un fragmento lítico de molino y tres fragmentos de escoria.

Junto a estos materiales cerámicos destaca la presencia de un importante lote de instrumentos de hierros en perfecto estado de conservación:

- Dos almocafres.

-Dos picoletas-hachas.

- Tres podaderas.

- Dos cuchillos.

- Un formón.

- Tres sierras dentadas.

- Fragmentos de un rallador.

- Una llave.

Objetos de bronce:

- Un torques.

- Una fibula.

- Una bola perforada.

- Un arete de pendiente.

Por su parte los restos de fauna corresponden en primer lugar a oveja/cabra -ovis aries/ capra hircus - (8 restos, 47\%, 2 animales) seguidas de perro - canis familiaris-( 3 restos, $11,7 \%, 1$ animal), cerdo - sus domesticus - ( 2 restos, $11,7 \%, 1$ animal), buey - bos taurus ( 2 restos, $11,7 \%, 1$ animal), asno - equus asinus - ( 1 resto, 5,8\%, 1 animal) y ave no determinada ( 1 resto, 5,8\%, 1 animal).

\section{HIPÓTESIS DE INTERPRETACIÓN. EL EDIFICIO 1 COMO ESPACIO SACRO}

El edificio descubierto parcialmente en Pontós no parece tratarse de un simple espacio doméstico. Sus dimensiones y el número de ambientes nos hablarían de una casa considerable para los parámetros habituales en la edilicia doméstica del área ibérica catalana de los siglos III-II a. C. Sin embargo, el argumento fundamental para su interpretación viene dado por la presencia del altar de mármol.

El ara de mármol de la habitación 3 (Figs. 7 a 9).

Se trata de un altar, realizado en mármol blanco del Pentélico ${ }^{12}$. El cuerpo es circular y aparece estriado como un fuste de columna alargándose en la base para formar un plinto ancho y de perfil delicado: una escocia ligada a un caveto por una ranura intermedia. En su parte superior, las estrías terminan en un motivo decorativo con kyma de hojas lanceoladas situadas

\footnotetext{
${ }^{12}$ Según confirmación analítica de A. Alvarez (UAB).
} 

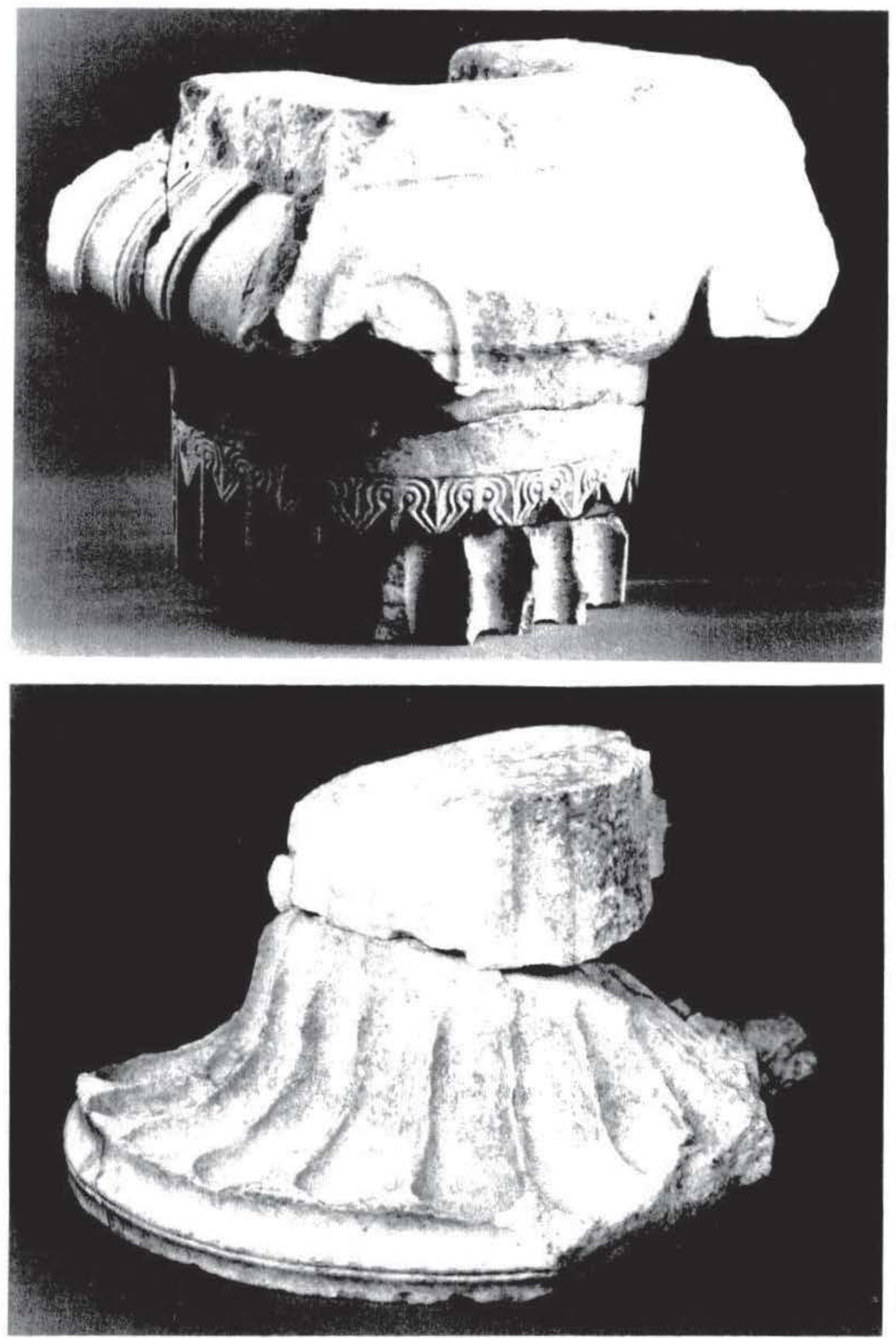

B

Figura 7. - El altar aparecido en el edificio I. A, coronación; B, base (fotografia Josep M. Boladeras). 

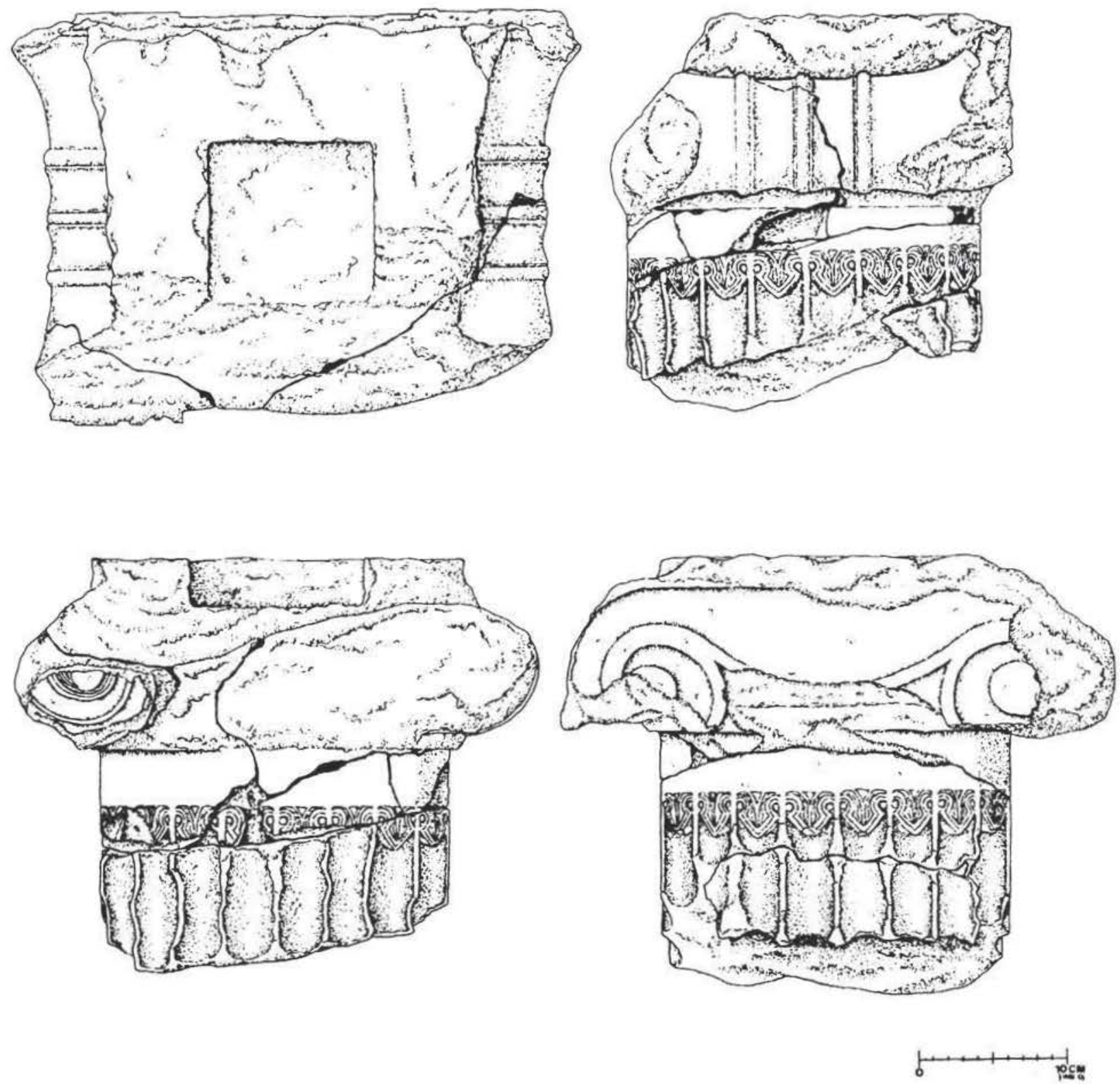

Figura 8.-Alzados de la coronación del altar. Se observa el rebaje para las libaciones (dibujo David Vivó). E. 1:5.

sobre las estrias, separadas por las propias aristas del fuste enmarcadas por perlas. El coronamiento del altar está trabajando como un capitel jónico clásico, con volutas pequeñas y equino imposible de definir por la erosión sufrida. En la mesa superior aparece un rebaje central cuadrangular de poca profundidad para colocar las ofrendas.

El elemento central de la discusión debe ser si la aparición de este altar, fragmentado en un nivel de abandono y por lo tanto no in situ, resulta suficiente para proponer un carácter sacro al conjunto. En realidad, toda casa en el mundo antiguo representa un espacio sacralizado, 


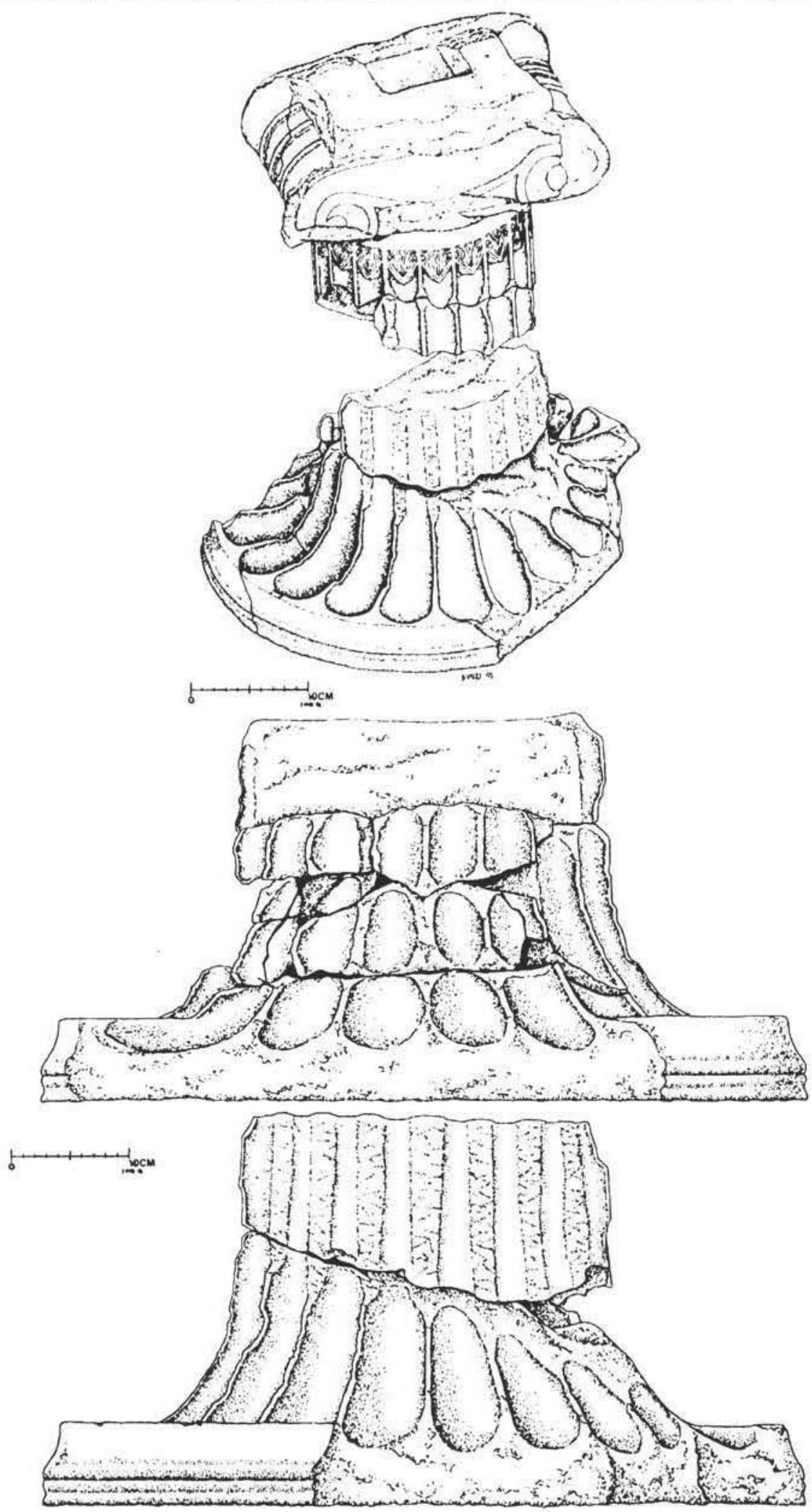

Figura 9.--Reconstrucción axonométrica del altar y alzados de su base (dibujo David Vivó). E. 3:20 y $1: 5$, respectivamente. 
protegido por diferentes ritos: de fundacion. en torno al hogar como nucleo central de la vida familiar, protección de las puertas, de la despensa y el corral, etc. Pero también es cierto que estos altares, en la antigüedad grecolatina, eran principalmente pequeñas arulae o simples pedestales de obra estucada ante un nicho o una escena pintada.

Por lo que conocemos sobre altares domésticos mediterráneos en época prerromana y en concreto en el mundo ibérico, debemos concluir que un altar jonico labrado en mármol pentélico importado representa un elemento excepcional para una "casa» iberica, aun cuando se tratase de la residencia de una jefatura ${ }^{14}$. Los paralelos que podemos encontrar para la pieza refuerzan esta imagen. En la propia Neapolis de Emporion donde uno de nosotros (JRdA) ha estudiado 34 casas tardorrepublicanas, la única picza similar que conocemos procede del santurario de Asklepios ${ }^{14}$ (Fig. 10).

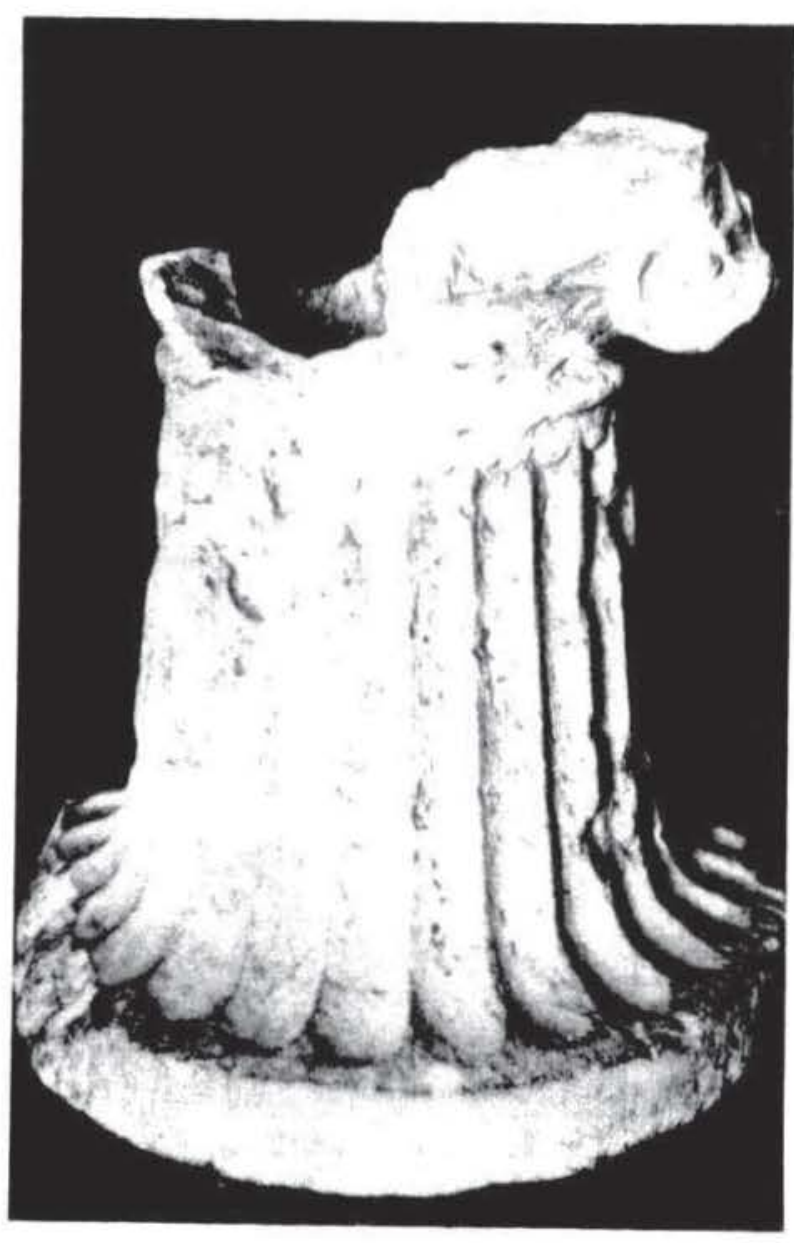

Figura 10. Altar del Asklepicion de Emporion (de A. Garcia y Bellido, op. cit., n. 15, lám. XVIII).

${ }^{13}$ Es cierto que en la Delos helenistica encontramos algunos altares domésticos de mármol pero son francamente minoritarios frente a su presencia habitual en santuarios o necrópolis, cf. Le Dinahet, M.T.1991: Autels monolithes et monolithoides de Delos, L espace sacrificiel, op. cit. n. 18, 109-120.

${ }^{4}$ Puig i Cadafalch, J.: Els temples d Empuries, Anuari del IEC, 1911-12, 33-22; Mar, R. y Ruiz de Arbulo, J.: Ampurias romana. ed. Ausa, 1993. 
Se trata de otra ara circular, también de mármol y parecido tamaño, con amplia base lisa, fuste estriado terminado en un cimacio de talón y mesa enmarcada por dos volutas ${ }^{15}$. Esta pieza, de concepción general menos cuidada que el ejemplar de Pontós, apareció en el interior del llamado templo $\mathrm{M}$, formando parte del depósito de mármoles que incluian la parte inferior de la estatua y serpiente de Asklepios, los pies de otra estatua sedente, una estatuilla de Artemis o Afrodita, etc. Su cronologia es imprecisa ya que forma parte de un santuario construido a principios del siglo II a. C. y vigente hasta mediados del siglo I d. C. De cualquier forma, la similitud del ara emporitana permite imaginar Emporion (o Rhode) como lugares de origen para el altar de Pontós ya fuera como puntos de desembarco de las piezas o bien como talleres donde ambas se realizaron.

El análisis estilistico de un ara de tipo griego con esta cronologia debe recurrir al tradicional trabajo de Yavis ${ }^{16}$, ahora complementado por la tesis de Rupp ${ }^{17}$, útiles como taxonomías pero muy pobres en ideas funcionales o cronológicas. Una reunión celebrada en Lyon en 1988 se ha dedicado de forma monográfica al tema de los altares de época clásica, principalmente helénica, su función, uso y los problemas de su clasificación y registro. Las propuestas de clasificación surgidas de esta reunión evidencian parecidos problemas sobre el dinamismo funcional de las estrictas series tipológicas ${ }^{18}$.

En espera del estudio detallado de esta pieza, que aqui simplemente presentamos, recordaremos que el uso del mármol y el carácter monolítico del altar de Pontós permiten situarlo con seguridad en época helenística (s. III a. C.?), momento en que los altares de obra estucada fueron en gran parte sustituidos por este nuevo tipo de piezas susceptibles de ser desplazadas.

Ignoramos cuál era la posición exacta de esta ara en el conjunto sacro de Pontós. Por sus características no debe tratarse del altar principal sino de una donación, una pieza de culto que imaginamos ofrendada por un mercader rodio o emporitano como prueba de fervor y magnificencia.

\section{La planta del edificio sacro (Fig. 11)}

Esta "casa" singular de Pontós cuenta con paralelos para su interpretación como un lugar sacro con algunos famosos ejemplos del área itálica. Los diferentes recintos del santuario empórico de Gravisca y los santuarios urbanos de Morgantina muestran, entre otros ejemplos, santuarios de planta "doméstica» en un amplio lapso cronológico de los ss. V al III a. C.

En Gravisca, puerto de Tarquinia, se consolidó a lo largo del siglo VI a. C. un emporion o mercado neutral de intercambios puesto bajo la protección de un mínimo de cinco divinidades diferentes; Hera, Afrodita, Deméter, Apolo y Adón ${ }^{19}$. En realidad, conocemos las construccio-

${ }^{15}$ Garcia y Bellido, A.: Hispania Graeca. Barcelona, 1948, lám. XVIII, reproducido en nuestra figura 10 .

${ }^{16}$ Yavis, C.G.: Greek Altars, St. Louis, 1949.

${ }^{17}$ Rupp, D.W.: Greek altars of the Northeast Peloponese, c. 750 to 275 BC, Ph. Dr. Dissertation, Ann Arbor (inédita). El lector se hará una idea del estilo consultando Rupp, D.W. 1991: The altars of Southern Greece: a tipological analysis, L'espace sacrificiel , infra, 303-306.

${ }^{18}$ Etienne, R. y Le Dinahet, M.T., L'espace sacrificiel (Lyon 1988), París, 1991. Ver especialmente Cassimatis, H., Etienne, R., y Le Dinahet, M.Th.: Les autels: problemes de classification et d'engistrement des données, ibid., 267-296.

${ }^{19}$ Boitani, F.: Comunicazioni sui risultati delle tre prime campagne di scavo effettuate nell' area 

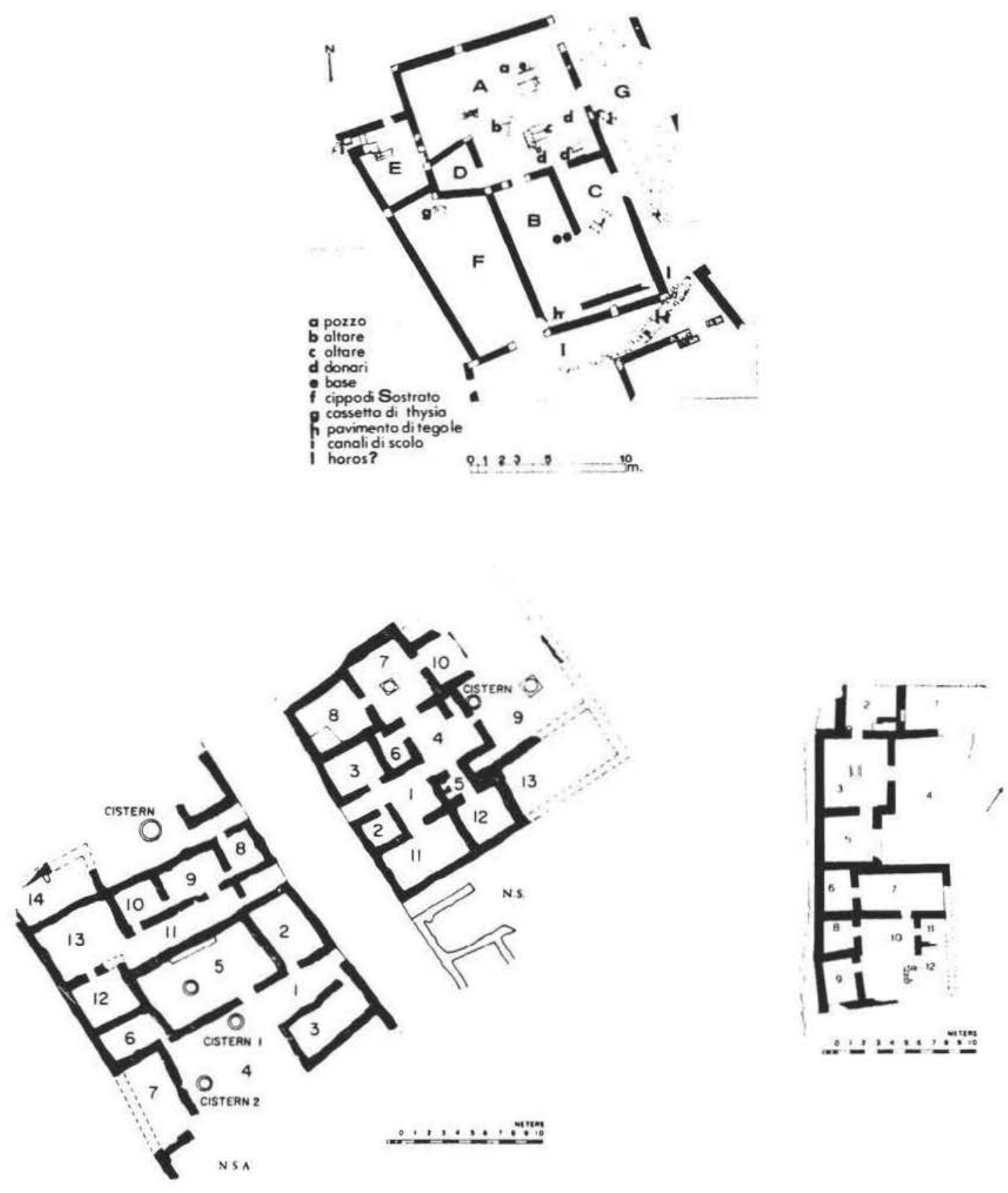

Figura 11.-Arriba, planta de uno de los edificios sacros de Gravisca (de Boitani, op. cit., n. 18); abajo, santuarios norte y sur de Morgantina (de Bell, op. cit., n. 22).

dell'antica Gravisca, en Symposio de Colonizaciones, Barcelona, 1974, 79-92; Torelli, M.: Il santuario greco di Gravisca, PdP, 1977, 398 y ss; Planta esquemática general en Torelli, M.: Etruria, Guid. Arch. Laterza, Roma-Bari, 1982, 161. Ver como estudio más reciente Pianu, G.: Gli altari di Gravisca, $L^{\prime}$ Espace Sacrificiel op. cit. n. 14, 193-199. 
nes de la fase final del santuario, vigente en los siglos IV-III a. C. (el lugar fue abandonado en los inicios del siglo II a. C.), con diferentes edificios organizados en torno a patios con altares, dedicados a divinidades etruscas: Uni, Turan o Vei. Por debajo, sin embargo, aparecen impresionantes rellenos con restos de la etapa de culto anterior, plagados de exvotos cerámicos (copas, jarras, lucernas, ungüentarios) y algunos bronces. Los epigrafes griegos con dedicatorias de mercaderes atestiguan las divinidades veneradas en el siglo $\mathrm{V}$ a. C. y el origen de los fieles, ricos aristócratas jonios también documentados en Naucratis e incluso siervos empleados como intermediarios de confianza en sus empresas ${ }^{20}$.

La sacralidad de los edificios queda evidenciada por la presencia de altares, basas de estatuaria y las riquísimas ofrendas votivas, pero las plantas de estos edificios, con salas organizadas en torno a patios, nada tienen que ver con la imagen que tradicionalmente nos hacemos de un templo clásico.

En Sierra Orlando (Sicilia), las excavaciones americanas han documentado el perimetro y el área central de Morgantina, la ciudad siciliota que Roma entregaria en el 211 a. C. al íbero Moericus y su tropa ${ }^{21}$. En el interior de la ciudad, las excavaciones han documentado diversos santuarios de culto ctónico, activos durante los siglos IV-III a. C., que junto a las necrópolis han proporcionado entre otros materiales más de 2000 prótomos, bustos y figuras femeninas de terracota ${ }^{22}$.

El santuario Norte (fig. 11 a), abandonado a fines del siglo III a. C. coincidiendo con la ocupación hispana, aparece como un gran conjunto doméstico («unpretentious house») organizado en torno a un patio. Las necesidades del culto provocaron su ampliación a otro edificio («North sanctuary annex») al otro lado de la calle. La definición sacra viene dada por la presencia de altares en algunos ambientes junto a abundantes depósitos votivos: monedas, thymiateria, vasos cerámicos y figuras de terracota, ofrendas de cereal, aceite y otros comestibles conservados en parte en depósitos enterrados y en parte dispersos en el nivel de destrucción ${ }^{23}$.

El santuario Sur, junto a las murallas, aparece como un edificio organizado en dos sectores en torno a sendos patios (fig. 11 b. 4 y 10). La habitación 2, donde apareció un gran número de terracotas, contenía un pequeño baño lustral y comunicaba con una habitación (3) con altar central. En la sala 1 se encontraba un vaso conteniendo el famoso tesoro de monedas romanas de plata datables entre el 220-210 a. C. ${ }^{24}$. En el espacio anexo, aparecen una sala con pithoi y terracotas (7), un baño (6) y un almacén con vasos y ánforas (9). Un gran número de terracotas aparecen en las salas 7 y 9 . La primera, además, contiene en el pavimento numerosas monedas de la segunda mitad del siglo IV a. C. Al igual que el santuario Norte, también este santuario fue abandonado tras la llegada de los hispanos en el 211 a. C. ${ }^{25}$.

${ }^{20} \mathrm{El}$ estudio fundamental para la prosopografía de los oferentes es el de Torelli, M.: Per la definizione del commercio greco-orientale: il caso di Gravisca, $P d P, 1982,304$ y ss.

21 Livio XXVI, 21.

22 Bell, M.: Morgantina Studies I. The terracottas, Princeton, 1981.

${ }^{23}$ Bell, ibid., 249-254.

${ }^{24}$ Se trata del famoso tesoro citado en todos los manuales como referencia para la aparición del denario y sus divisores junto a los victoriati. (v. p. ej. T. V. Buttrey: The Morgantina Excavations and the Date of the Roman Denarius, en Idem et alii, Morgantina Studies, the Coins, Princeton, 1989, pp. 215-220.

${ }^{25}$ Bell, 1981, op. cit. n. 22, 254-256. 
Junto al ágora, entre el graderio que la limita por el sur y el vecino teatro, encontramos un tercer santuario, de nuevo con habitaciones rodeando un patio. En éste se situaba un altar, con recinto circular en torno, conteniendo un depósito de lucernas, vasitos votivos y láminas de plomo con maldiciones a terceros invocadas a Gé (la Tierra), Hades y Hermes. Junto al patio, aparece una exedra con asientos y dos ambientes anexos y una sala con altar precedida de un vestibulo. A poca distancia, otro edificio contenia un gran conjunto de lucernas que se han relacionado de nuevo con un depósito sacro de tipo ctónico ${ }^{26}$.

Estos paralelos permiten defender el carácter sacro del edificio de Pontós, aunque todavía es pronto para definir la función precisa de las diferentes salas del edificio, ya fueran lustrales, de culto, de banquete o almacenes de ofrendas. Para corroborar esta imagen contamos con un segundo elemento de aproximación entre los depósitos de abandono de la habitación 1 a los que nos referiremos más adelante.

\section{¿Por qué un santuario?}

En ausencia de un templo canónico hemos de recordar que en el mundo antiguo la noción de un santuario corresponde en realidad a un área delimitada, en la cual los fieles podían ponerse en contacto con la divinidad tutelar por la presencia de un altar de sacrificios, mediante un ritual establecido por la tradición o la existencia de un reglamento específico. Delante de un árbol, junto a una fuente, en una gruta o en un cruce de caminos podríamos encontrar un santuario señalado siempre por la presencia del altar y la definición de su témenos.

Sobre el altar, las ofrendas eran devoradas por el fuego "ascendiendo» o «descendiendo» hacia las divinidades que los recibían. Para los dioses olímpicos se trata del bomós, o altar sobreelevado; para los dioses ctónicos o subterráneos ${ }^{27}$ se trata del bóthros, un altar provisto de un agujero central para el descenso de la ofrenda y las eschárai, altares/hogares situadas a ras de suelo.

Los aspectos rituales motivaban que junto al sacrificio, necesario para poder contactar con el dios, apareciese también la presencia de la ofrenda o exvoto, anáthema ó ágalma, un regalo material ofrendado al dios, un «objeto trabajado con arte» como las estatuillas mencionadas en el reglamento del siglo III a. C. del santuario de Despoina en Lykosura ${ }^{28}$. Estos dones, teóricamente inviolables y sagrados como posesión de la divinidad, podían ir colgados de las ramas del arbolado, arrojados al agua de un estanque, un río o al interior de un simple depósito, quedar amontonados en bancos y colgados de las paredes, o bien, cuando se trataba de divinidades ctónicas, ser colocados bajo tierra en una ofrenda también denominada bóthros, «accesible a lo subterráneo».

En ocasiones, cuando los dones alcanzaban un volumen excesivo, quedaban dañados por un incendio o el simple paso del tiempo, el sacerdocio podía recurrir a la refundición de los

${ }^{26}$ Cf. AJA 1983. Ver breve descripción en Coarelli, F. y Torelli, M.: Sicilia, Guid. Archeol. Laterza, Roma-Bari, 1984, 194-195.

27 De la palabra griega cthon, que expresa la tierra y también su profundidad.

${ }^{28}$ IG, V 2, 514; Sokolowski 1969, num. 68, El reglamento regula en primer lugar el vestido de los fieles (1.2-13) y en segundo lugar las reglas del sacrificio (1. 14-19): «aquéllos que sacrifiquen utilizarán olivo, mirto, tortas de miel, granos de cebada pelados, estatuillas (agalma[ti]), amapolas blancas, pequeñas lucernas, perfumes, mirra, hierbas olorosas...» 
objetos metálicos o al simple reaprovechamiento en nuevas obras y rellenos constructivos ${ }^{20}$. Fruto de esta situación es el descubrimiento arqueológico de ricos depósitos votivos que describimos habitualmente con los términos latinos de farissae ${ }^{30}$ y stipites ${ }^{31}$.

\section{El bóthros del silo lol (zona 4)}

Resulta habitual que un silo fuera de uso, como fosa cavada en el suelo, se convirtiera en un pozo negro o en un vertedero de desperdicios. En el interior de hábitats es también frecuente encontrarlos colmatados en un momento concreto, por ejemplo para evitar el hundimiento de nuevas construcciones que pasaran por encima. Como vertederos, encontramos en sus rellenos abundancia de materiales cerámicos, en muchas ocasiones piezas completas o casi completas, objetos metálicos, fauna, etc. ${ }^{32}$. No obstante, en el caso del silo 101 la secuencia estratigráfica y los hallazgos materiales demuestran que se trata de un depósito votivo intencionado.

\section{El hogar/altar}

El primer hallazgo determinante lo constituye el hogar situado al fondo, sobre el relleno inferior. El análisis de sus cenizas ha proporcionado minúsculos restos vegetales (pinus sylvestris, quercus ilex, entre los carbones de madera, y un grano de trigo, dos fragmentos de aceituna, etc., entre productos agrícolas). Debe tratarse de los restos de la ofrenda alimenticia a la divinidad. Como tal puede ser definido como un auténtico altar en fosa, una eschára destinada a ser utilizada una única vez y cuyo carácter queda reforzado por la inmediata presencia de una cabecita femenina de terracota.

\section{La cabecita de terracota (fig. 12)}

Se trata de una cabeza perteneciente a una figura femenina de terracota, de la cual fue cortada. Tiene $3,5 \mathrm{~cm}$. de altura, presenta los ojos hundidos, la cabeza ladeada a la derecha y luce un peinado «de melón» ceñido por una diadema y acabado en un moño alto. En las orejas lleva pendientes de disco. La pasta es de color crema oscuro como resultado de una cocción oxidante, sin restos de pintura, de aspecto externo algo tosco.

La producción de figuritas femeninas de terracota, drapeadas y en posición alzada, gozó de gran popularidad durante la época helenistica junto a los personajes teatrales, grotescos o

${ }^{29}$ En el ritual itálico los dones hechos a los dioses eran distinguidos del mobiliario cultual y podian ser reutilizados (las leyes sacras describen esta acción como "volver de nuevo profano» el objeto en cuestión). Ver a este respecto las reflexiones de De Cazanove, O.: Ex-voto de I'Italie republicaine: sur quelques aspects de leur mise au rebut, Les sanctuaires celtiques et le monde mediterraneen (1989), París, 1991, 203-214, espec. 210. Ver también Rey-Vodoz,V.: Les offrandes dans les sanctuaires galloromains, ibid., 215-220, espec. 219 con referencia a la lex aedes Furfensis (58 a.C.).

${ }^{30}$ El sentido de favissa transmitido por las fuentes (Aulo Gelio/Varron y Festo) une los conceptos de almacenamiento de viejos objetos o imágenes sacras con el de cisternas de agua, cf. $D A$, s.v. favissae (H.Thedenat) y sobre todo Hackens,T.: Fauissae, Etudes Etrusco-italiques, Lovaina, 1963, 71-99.

${ }^{31}$ Desnier, J.L.: Stips, Revue de la Histoire des Religions, 204, 1987, 219-230.

${ }^{32}$ Ver por ejemplo en Emporion, el silo Gall 1 colmatado por la construccion del foro en AAVV, El Forum Romà d'Empuries, Barcelona, 1984; o el relleno en la Neápolis del "silo de las ánforas» en Ruiz. de Arbulo, infra, n. 54. 
exóticos. Aparecen documentadas preferentemente como ofrendas religiosas o bien formando parte de ajuares funerarios ${ }^{33}$.

El conocimiento de estos materiales se produjo en la segunda mitad del siglo XIX a partir de los grandes conjuittos suministrados por las necrópolis de Tanagra ${ }^{34}$ en Beocia y Myrina ${ }^{16}$ en Eolia. Al tratarse de piezas realizadas a molde, fáciles de producir y de copiar, los centros de producción fueron muy diversos y su presencia se extiende por todo el mundo helénico. La cabecita de M. C. de Pontós luce un peinado denominado «de melón», con bucles paralelos peinados hacia atrás y recogidos en un moño alto ceñido por un cordón. Es un peinado muy frecuente en la coroplastia helenística que se inicia a fines del siglo IV a. C. en Tanagra y Atenas ${ }^{36}$ difundiéndose en los siglos III y II a. C. por Grecia, Asia Menor, Italia y Sicilia ${ }^{37}$. El moño alto, a su vez, deriva del lampadion (pequeña antorcha), tipico de mediados del siglo IV a. C. La presencia de una cinta o cordón sobre las sienes sustituyendo la diadema (stephané), es también habitual en los peinados «de melón» ${ }^{3 x}$.

La factura de la pieza, esquemática y poco cuidada, sin apenas detalles ni decoración incisa, hacen pensar conjuntamente en un momento avanzado de la producción, en los siglos III/II a. C. y también en la factura de un taller secundario. Entre las 2000 terracotas de Morgantina encontramos los paralelos más cercanos en diversas cabecitas correspondientes a los niveles de abandono de los cultos ctónicos durante la ocupación hispana de la ciudad en el siglo II a. C. ${ }^{34}$. Su producción, tras el saqueo de Siracusa por Marcelo en el 212 a. C., se asocia a los talleres de Kenturipa, aliada de Roma desde el 263 a. C. y una de las más importantes ciudades de Sicilia en los siglos $॥$ y I a. C., cuyas necrópolis han proporcionado también numerosa coroplastia de estos mismos tipos ${ }^{40}$. Por lo demás, recordemos que la producción de coroplastia es también frecuente en la Magna Grecia, a partir de los talleres de Tarento, que alcanzaron la categoria de auténtica escuela ${ }^{41}$, difundida hasta los grandes centros campanos como Capua o Neapolis ${ }^{42}$. En el Lacio, los depósitos sacros republicanos del santuario de Satricum han proporcionado igualmente una amplia colección: 395 figuras enteras, 150 fragmentos y 300 cabecitas ${ }^{+3}$.

${ }^{33}$ Ver como obras de introducción Higgins, R.: Greek Terracottas, Londres, 1967; Higgins, R.: Tanagra and the figurines, Princeton, 1986; AAVV, Les Terres cuites grecques, Dossiers Histoire et Archeologie, 81, 1984.

34 Higgins, Tanagra..., ibid.

35 Pottier, E. y Reinach, S.: La necropole de Myrina, París, 1887; Besques, S.: Les terres cuites de Myrina, Archeologia, 1982.

${ }^{36} \mathrm{~V}$. restitución moderna en Higgins, op.cit. n. 33, fig. 143.

${ }^{37}$ Higgins, op.cit. n. 33 ; Bell op.cit. n. 21 . Rainini, I. et alii, Valle d'Ansanto. Il deposito votivo del santuario di Mefite, Not. Scavi, 1976.

${ }^{36}$ Comparar p.ej. la cabecita 558 de Morgantina, en Bell, op.cit. n. 22.

39 Bell, op.cit. n.22, 75-76.

40 Libertini, G.: Centuripe, Catania, 1963.

${ }^{41}$ Loiacano, D.: Le terrecotte figurate, Taranto. Il Museo Archeologico, Taranto, 1985, 337-411.

${ }^{42}$ Bonghi-Jovino, M.: Figurines hellenistiques en Grande Grèce, Dossiers Hist. et Archeologie, 81, 1984, 81-90.

${ }^{43}$ Beaufort, J.: Satricum. Una citta latina, Florencia, 1982; Van Tongeren, A.: Terracotta figuren von Satricum. De terracotta' a van het Tunagra-Myrina Type vit her Hellenistiche Votiefdepot behorend bij de Tempel te Satricum, Tesis mec., Nimega, 1983 (cit. en Cazanove, op cit. n.29). 

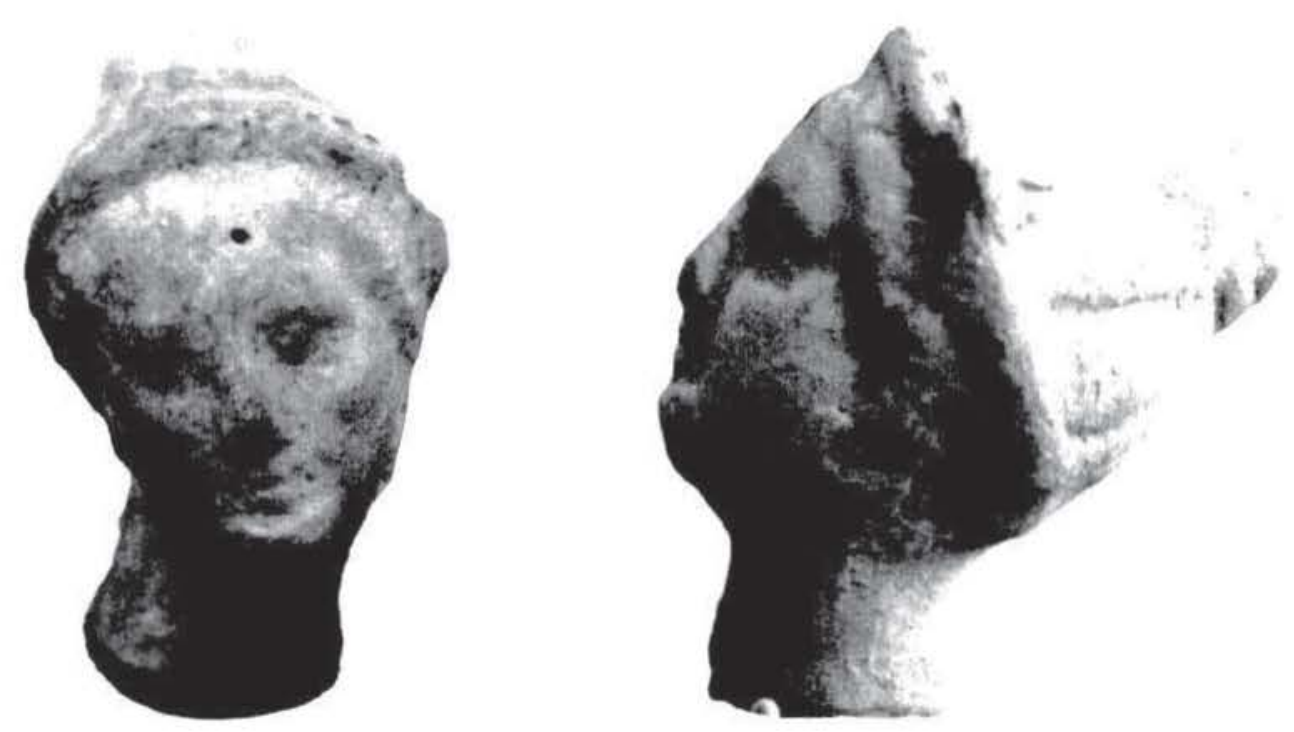

Figura 12. Cabecita femenina de terracota aparecida junto al hogar del silo I0I.

L a llegada a Pontós de este original se produjo con seguridad por intermedio de los puertos del golfo. Los paralelos más próximos se encuentran en contextos funerarios de la necrópolis de incineración de Las Corts, en Emporion, todos ellos datables de forma aproximada en los siglos III-II a. $\mathrm{C}^{+4}$. Por otra parte, recordemos en lo relativo a la producción que en los hornos cerámicos de Rhode, activos en el siglo III a. C., apareció un molde de pasta massaliota para producir prótomos de Deméter ${ }^{45}$

Resulta frecuente que estas figuritas femeninas se rompicran por el cuello. En los catálogos de la coroplastia de los grandes museos europeos aparecen abundantes colecciones de cabecitas. En otras ocasiones, como ocurre en hallazgos atenienses del siglo IV a. C. ${ }^{40}$ abundan más los cuerpos que las cabezas. Sin embargo, una presencia casi exclusiva de cabecitas como la observada en la necrópolis de Las Corts pudo obedecer también a un hecho intencionado: la rotura voluntaria de la figura como simbolismo de su entrega a la divinidad. La presencia de cabecitas aisladas rotas voluntariamente junto a figuras enteras ya habia sido observada en la necrópolis de Myrina. Como en Emporion, también en Tanagra, Myrina, Morgantina o Kentoripa varia el número de las figuras presentes en las tumbas, de una o dos hasta grandes conjuntos con decenas de ejemplares.

"4 Almagro, M.: Las necropolis de Ampurias (vol. 1), Barcelona, 1953, 275 y ss.: figura de la tumba 17 y cabecitas de las tumbas 72 (seis ejemplares), 86 ( un ejemplar), 88 (cuatro cabecitas, una fragmentada, tres desaparecidas), 104 (tres cabecitas y una terracota de cabeza de Deméter), 115 (un ejemplar). 129 (una cabecita y cuatro terracotas de Deméter fragmentadas) y 131 (un ejemplar).

4 Martin, M.A.: Noticia de la troballa d'un motlle per a fabricar terracotas procedente de Roses, Revista de Gerona, 85, 1978, 375.

th Thompson, D.B.: The origin of Tanagras. A.A. 70, 1966, 51-63. 
Ya sea en un contexto votivo o como ajuar funerario, estas figuras femeninas aparecen siempre en estrecha relación con los cultos a Deméter y Core. Se trata de la unión de dos ritos complementarios, por un lado el ciclo agrario anual representado por el rapto de core y su búsqueda por Deméter y en segundo lugar la theogamia o matrimonio divino entre Core, ahora Perséfone y Hades.

Esta imagen se corrobora por la asociación votiva entre estas figuritas y las terracotas con cabeza de Deméter. Asi ocurre en el depósito del Bordisal de Camarles, en la antigua línea de costa junto al Delta del Ebro, donde una treintena de terracotas de Deméter aparecen asociadas a dos figuritas femeninas drapeadas y cerámicas áticas del siglo $\mathrm{IV}^{47}$. Idéntica asociación aparece también (en la vertiente funeraria de los cultos) en la necrópolis emporitana de Las Corts (añadir a los ejemplos citados las terracotas de Deméter de las tumbas 88, 102, 123 y 158). Recordaremos por último que Pontós había ya proporcionado un lote de terracotas con cabeza de Deméter en el relleno del silo 28.

Un excelente ejemplo de la presencia de estas figuritas femeninas drapeadas en depósitos votivos dedicados a Deméter lo proporciona un bóthros excavado en el templo de Deméter en Priene. Este bóthros contenía 212 terracotas representando a las diosas, Baubos, Nikes, danzantes, erotes y figuritas femeninas en posturas diversas junto a hidrias en miniatura, palomas y jabatos, ahora conservados en el Museo de Berlín ${ }^{4 x}$.

La presencia aislada de esta cabecita junto a los restos del hogar/altar central permite descartar un culto heroico, que también hubiera podido recibir ofrendas subterráneas y conduce directamente, junto con las herramientas agricolas, al ciclo de Deméter y CorePerséfone ${ }^{49}$.

\section{Las piezas discoidales}

Entre los materiales del depósito aparecen veintidós discos de cerámica recortados de vasos y ánforas. En otros depósitos de Pontós estos discos han aparecido también en gran número ${ }^{50}$. Algunos son discos de un cierto tamaño, utilizados habitualmente como opérculos para tapar las ánforas, pero la mayoría son discos pequeños utilizados probablemente como pesas de telar o de uso para la contabilidad.

Los pintores áticos representaron a menudo escenas de trabajo en el interior del gineceo, con el cardado de la lana y la realización de tejidos en el telar como actividades destacadas. En los telares, la tensión de los hilos era lograda mediante pesos colgados, los habituales pondera troncocónicos, bien documentados en los hallazgos arqueológicos. Sin embargo, en estas representaciones aparecen también pequeñas fichas destinadas a la separación de hilos finos en telares o trabajos de mayor precisión. Z. Castro dedicó un trabajo a este tema demostrando como los discos de pequeño tamaño recortados en cerámica debían ser testimonio de esta

47 Vilaseca, L.: Hallazgos helenísticos en Camarles (Tarragona), Ampurias, 15-16, 1953-54, 355358; Pallarés, R., Gracia, F., Munilla, G.: Culto griego en la desembocadura del Ebro, Saguntum, 20 , 1986, 123-149. En nuestra opinión se trata del depósito votivo de un santuario que debería situarse en la inmediata proximidad.

${ }^{4 k}$ Heilmeyer W.D.: Antikenmuseum Berlin. Die ausgestellten Werke, Landshut, 1988, 190-191.

${ }^{49}$ Ver infra el paralelo de su disposición con los depósitos G 5 y G 7 del thesmophórion de Bitalemi.

${ }^{50}$ v. infra., 295 discos en silo $25 ; 76$ discos en silo 26. 


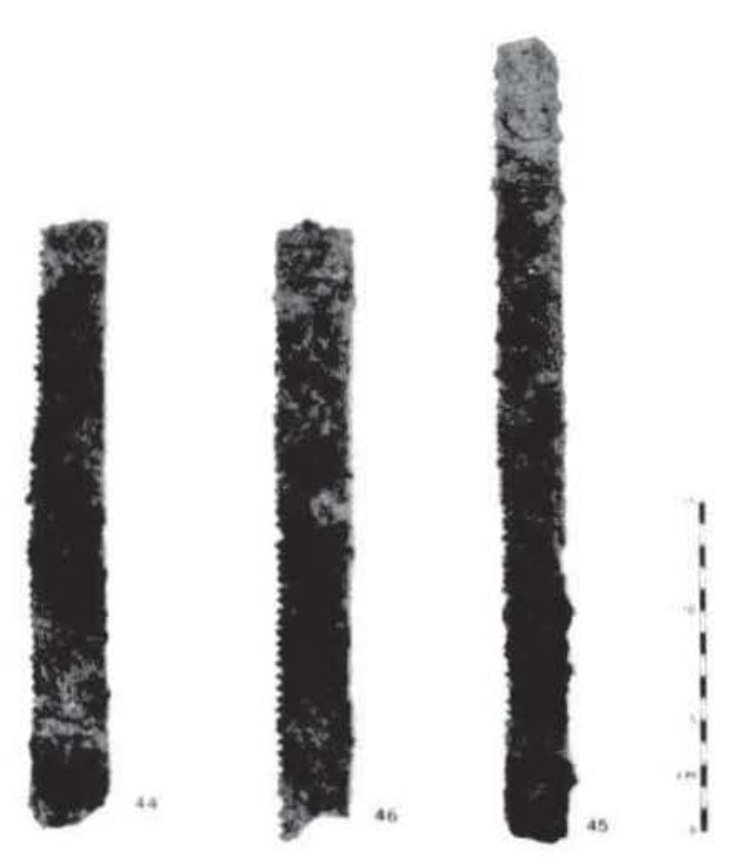

$\Lambda$
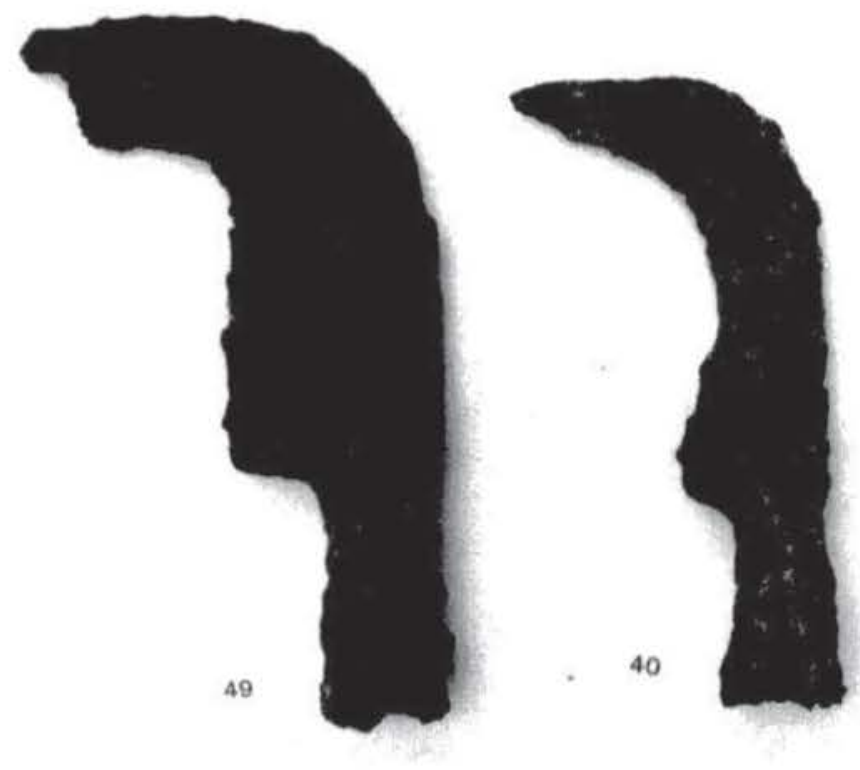

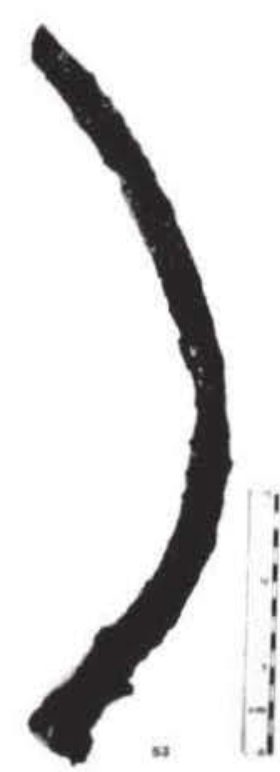

B

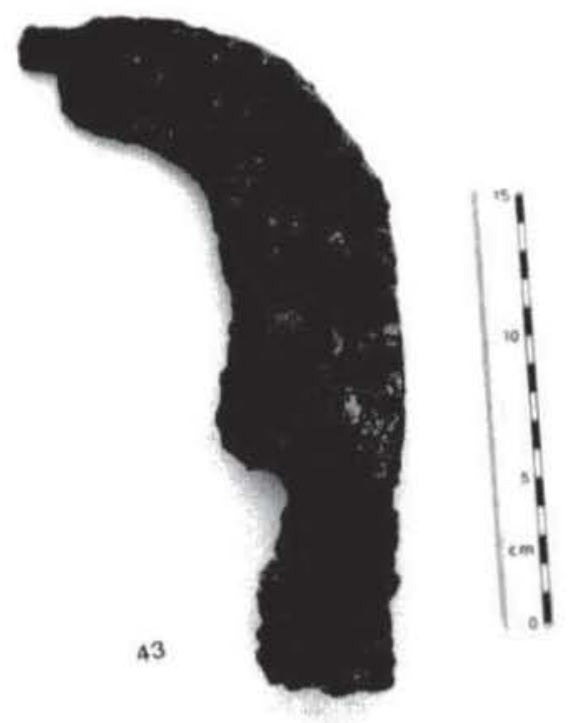

C

Figura 13. - Materiales del depósito votivo del silo 101: A, sierras: B, hoces; $\mathrm{C}$, podones. 


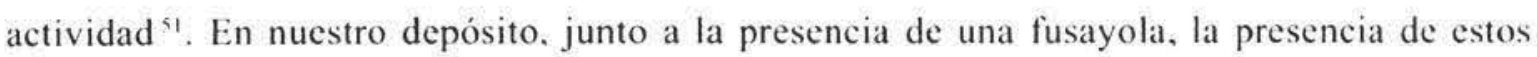
discos deberá interpretarse como una ofrenda caracteristica de la vida femenina

\section{Los hierros agricolas (fig. 13)}

La presencia en el depósito de un amplio muestrario de herramientas agrícolas, en muy buen estado de conservación y todavia en algunos casos con restos de los mangos de madera, permite una vez más desechar la hipótesis de un vertedero. Las herramientas agrícolas son una de las ofrendas caracteristicas a Deméter y Core, diosas de los cereales y protectoras del ciclo agricola de siembra, germinación y cosecha. Como veremos más adelante, estas ofrendas podian consistir en la dedicatoria directa de las herramientas, como se documenta en la fase arcaica del thesmophorion de Bitalemi ${ }^{53}$ o bien por su sustitución por hoces votivas como ocurre en el santuario de Deméter en Heraclea. En ambos ejemplos, también los cuchillos, utilizados durante el banquete ritual, eran ofrendados a la divinidad.

No insistiremos en este trabajo sobre las características técnicas de estas herramientas, actualmente en proceso de restauración y que serán fruto de un estudio específico. Su enumeración se encuentra en el ya citado listado de materiales del depósito. Ilustramos aqui algunos ejemplos.

\section{El conjunto vascular. (figs. 14 a 17 )}

El conjunto cerámico permite en primer lugar una datación precisa del depósito, ya que la asociación de formas antiguas de campaniense A, perduración de barniz negro de Rhode, ánforas grecoitálicas evolucionadas (altas, con pivote macizo y labios de borde poco saliente), ánforas púnicas, cerámica gris de la costa catalana y cerámica ibérica pintada o lisa, es característica de la primera mitad del siglo II a. C. ${ }^{54}$. Ahora bien, definir con precisión las características rituales de estos materiales nos resulta de momento imposible. Las ánforas fueron depositadas enteras y ya vacías de sus contenidos. Se trata de ánforas grecoitálicas contenedoras de vino y de ánforas ibéricas de contenido no preciso (quizás simplemente agua). En ambos casos debemos imaginar que se trata de contenedores de productos consumidos durante el banquete sacro.

Junto a las ánforas, encontramos un cierto simbolismo en el reparto funcional de la escasa vajilla que las acompaña: dos cuencos y un plato de barniz negro, un cálato, un ascos, un mortero, un ungüentario. Piezas que resumen y simbolizan funciones distintas de aseo y lustra-

51 Castro, Z.: Piezas discoidales en yacimientos ibéricos del NE de Catalunya, Cypsela, 2, 1976 , 173-195; donde se analizan diferentes posibilidades (tapaderas, ficha de juego, sistemas de cómputo, inclinándose por la opción textil).

${ }^{52}$ v. infra el paralelo de los póndera troncocónicos ofrendados a la diosa en el thesmophórion de Bitalemi. Para la fusayola ver también el trabajo de Castro, Z.: Fusayolas ibéricas, antecedentes y empleo, Cypsela, 3, 1977, 177 y ss.

$53 \mathrm{v}$. infra.

${ }_{54}$ Mar, R. y Ruiz de Arbulo, J.: Sobre el ágora de Emporion, AEspA, 61, 1988, 39-60; Ruiz de Arbulo, J.: Contextos cerámicos de la primera mitad del siglo II a.C. en la Neápolis emporitana, Homenaje a M. Tarradell, ed. Curial, Barcelona, 1993, 629-646. 

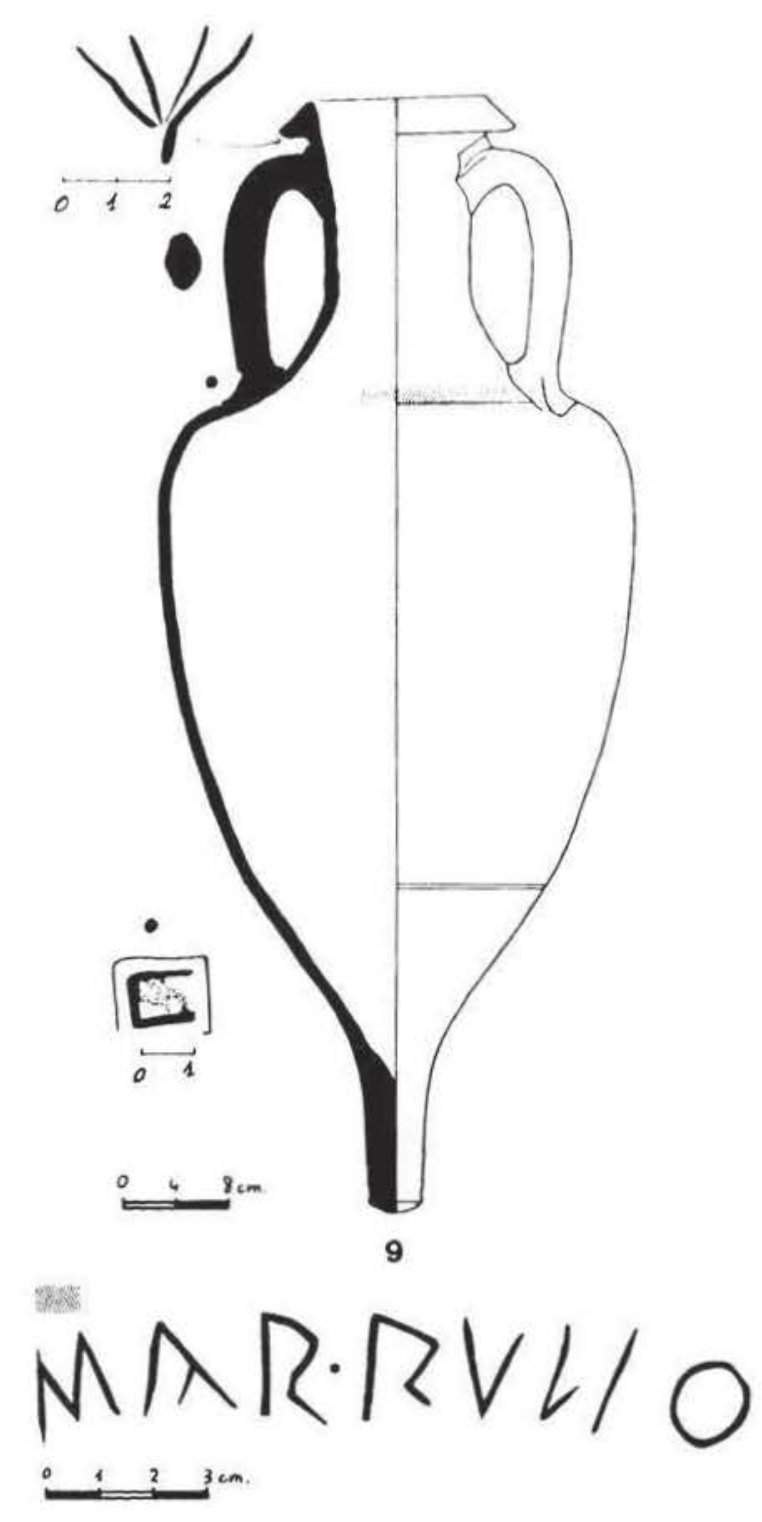

Figura 14.-Una de las ocho ánforas grecoitálicas del depósito votivo del silo 101. Ésta con la inscripción incisa MAR.RVLIO y otros signos. E. 1:8 para el ánfora.

ción (ungüentario), transformación de productos (mortero), contenedores preciados (cálato) y decoración y consumo en mesa (ascos, cuencos y plato de barniz negro).

Elementos de vestuario y otros

El vestuario aparece representado por escasas piezas de bronce (fibula, torques, botón, anilla, bola perforada). Como en el caso anterior se trata de ofrendas habituales, en gran parte propias del atuendo femenino, características de los depósitos votivos. Junto a ellas, el anzuelo 


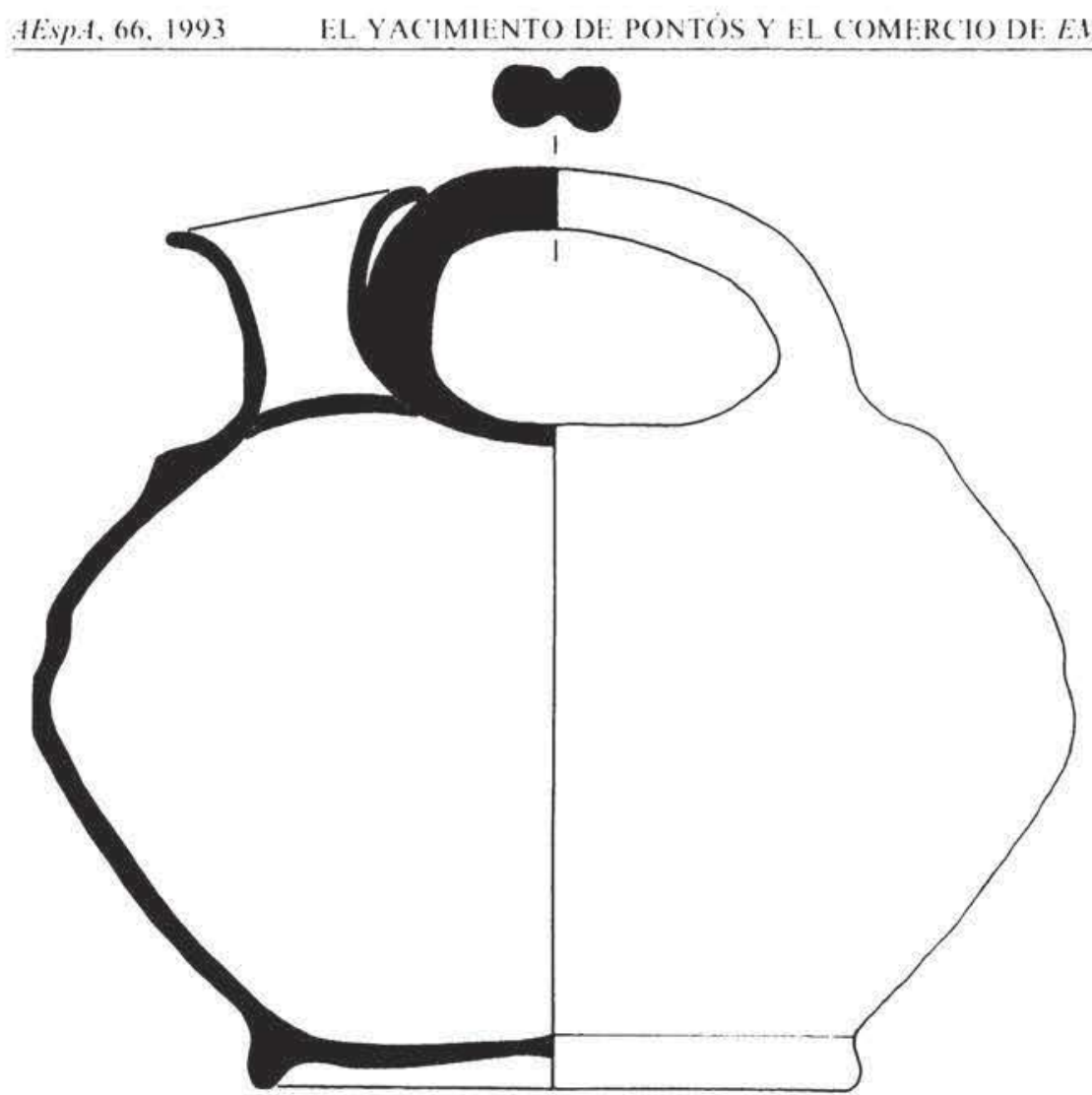

A
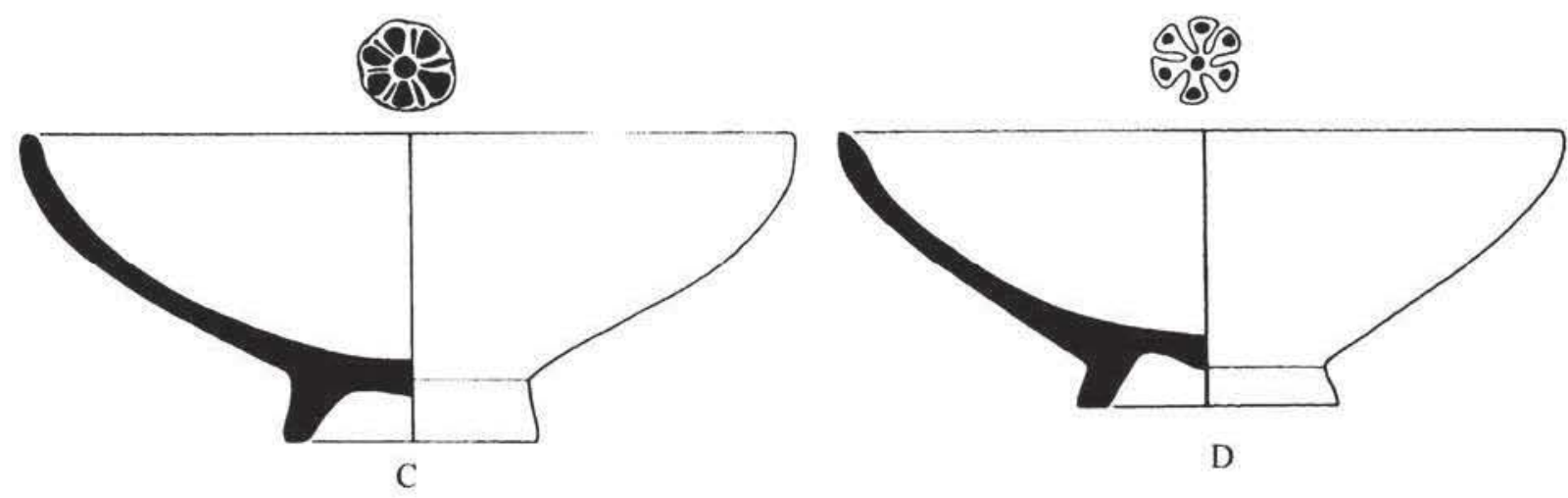

D

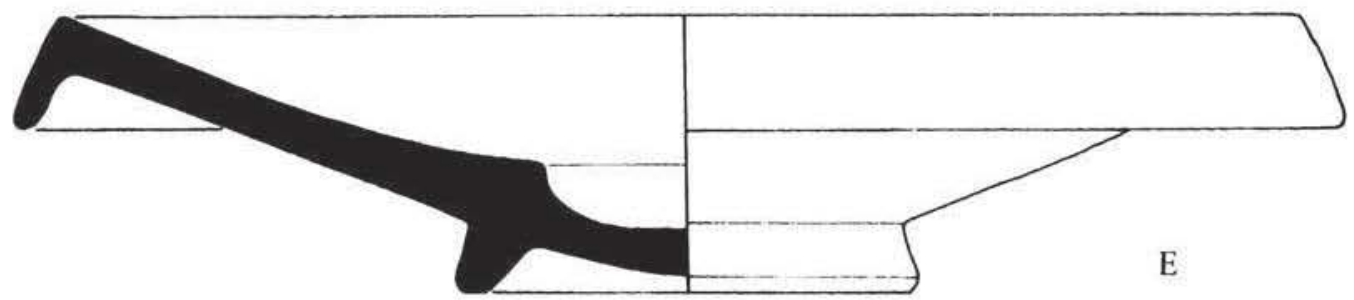

Figura 15.-Materiales cerámicos del depósito votivo del silo 101. A, ascos en cerámica ibérica; B, ungüentario; C, cuenco de barniz negro Lamb. 27, del taller de Rosas; D, cuenco de barniz negro Lamb. 27, de campaniense A; E, plato de barniz negro Lamb. 23, de campaniense A. E. 1:2. 
recuerda otras actividades economicas tradicionales (la pesca en los rios y lagunas cercanos) que tambien eran puestas bajo la protección de la divinidad.

Laloracioin votiva de otros hallazgos

$1 /$ relleno votivo del silo 101 permite efectuar una valoración análoga de otros hallazgos de Pontos hasta ahora de interpretación dudosa c inconexa.
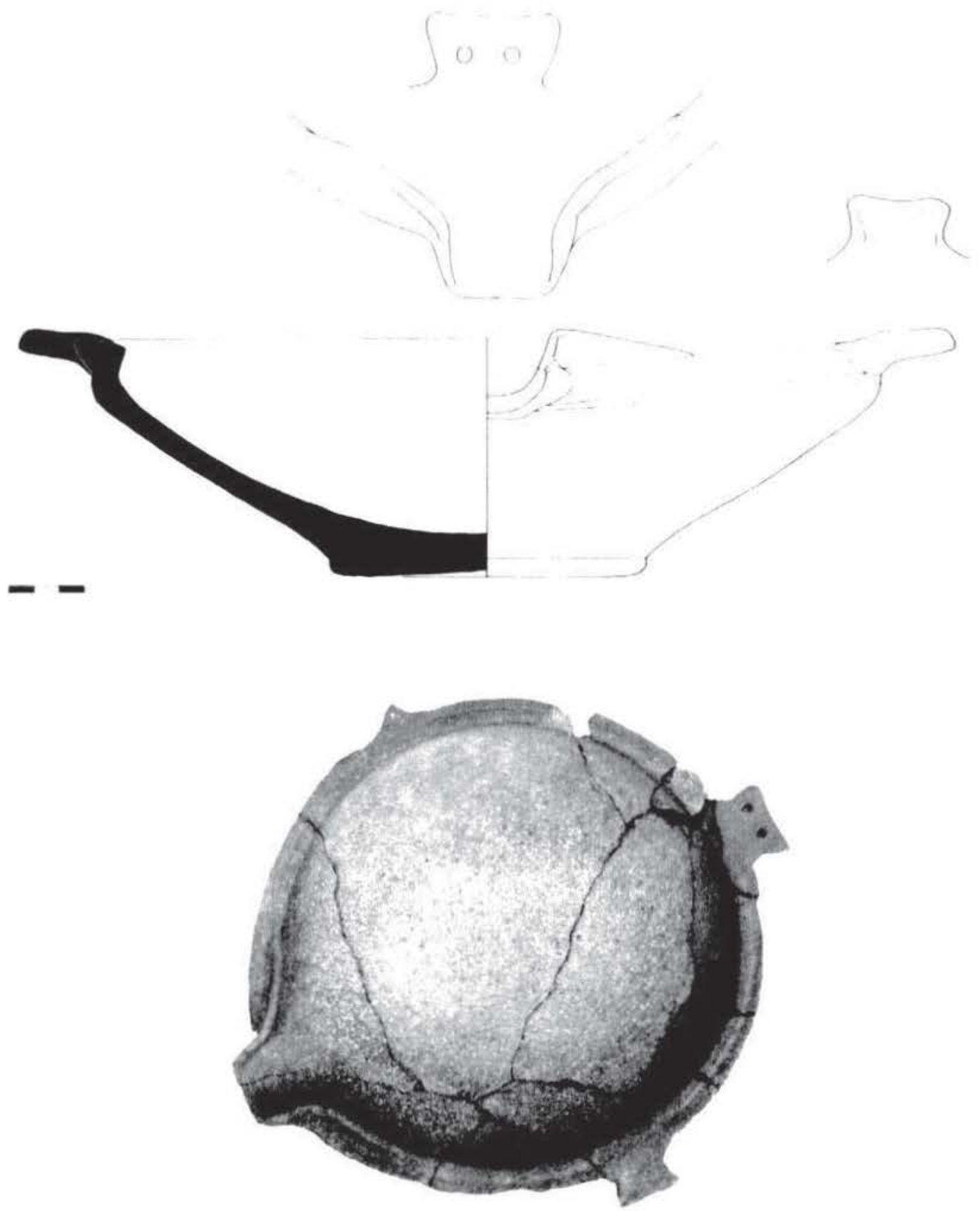

Figura 16.--Mortero del depósito votivo del silo 101. E. 1:3. 

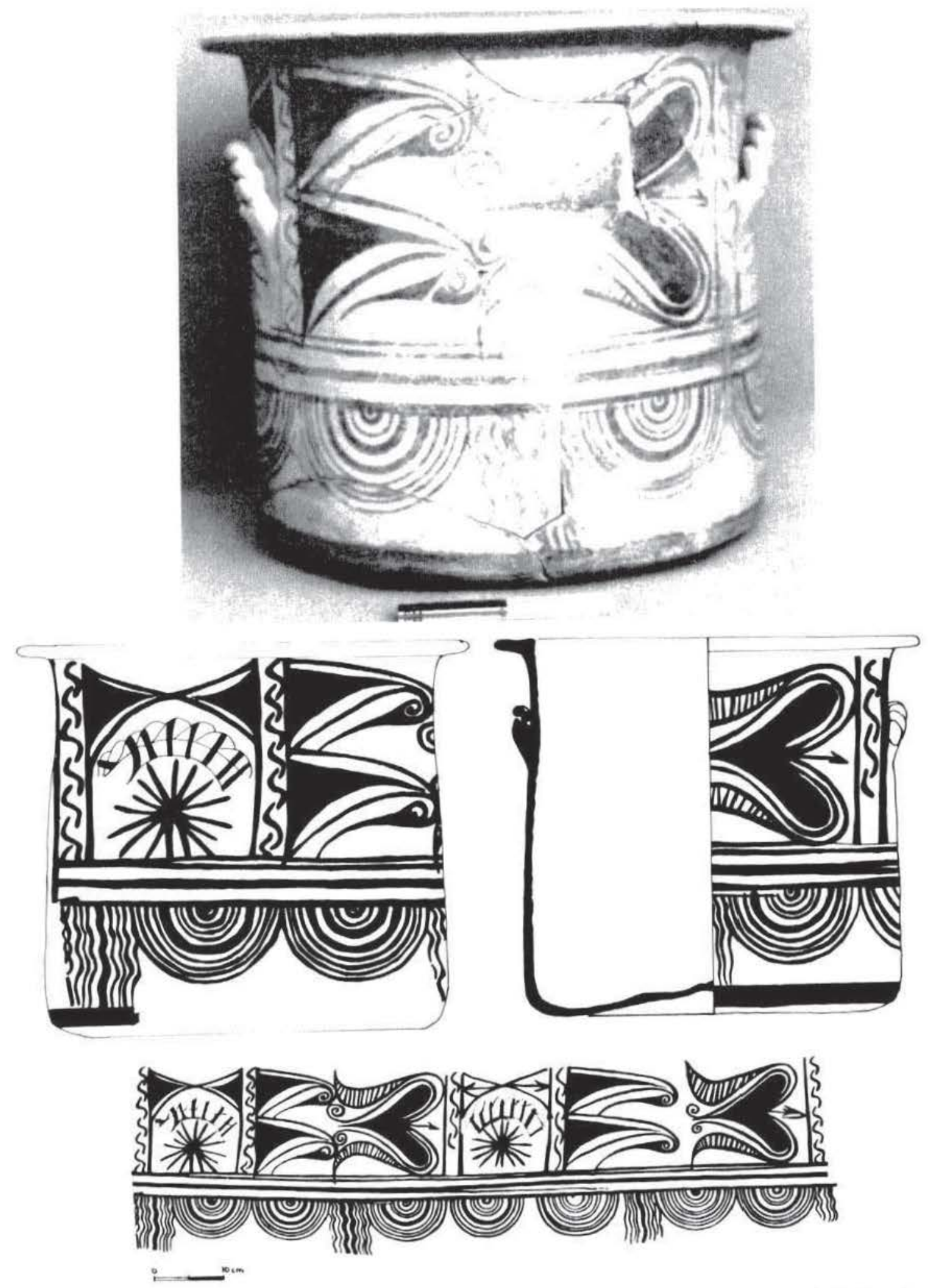

Figura 17. Cálato del depósito votivo del silo 101, cerámica ibérica pintada, del taller de Fontscaldes. E. 1:10. 


\section{Eil relleno del silo 26}

Presentado por Martin en el XV CNA de Lugo de $1977^{55}$ el relleno de este silo, en apariencia de interpretación compleja, presenta una casi total analogia con el depósito que acabamos de estudiar.

El silo presentaba en el fondo un estrato estéril (III) con arenas y cantos rodados. Encima aparecieron los restos de un hogar formado por piedras y tierra arcillosa quemada y sobre el mismo «abundante material cerámico, entre el que habia varias piezas de cerámica emporitana y hecha a mano completas, rotas, pero con los fragmentos en conexión" "st, seguida por un estrato de colmatación con abundantes materiales (II) y un estrato superior ya alterado por intervenciones posteriores (I). Entre los materiales del estrato II se mencionan campaniense A, cerámicas ibéricas y emporitanas, "grandes piezas ovoides y bicónicas" (que podriamos considerar vasos de agua similares a las hidrias tan frecuentes en los depósitos itálicos), ánforas «de boca triangular» (hemos de suponer que grecoitálicas ya que el resto del contexto no permite pensar que se trate de Dressel 1), ánforas «de filtro» (Mañá D) y otras ánforas púnicas e ibéricas. Se señalan también restos óseos atribuibles en parte a oveja.

El inventario de estos materiales permite dar al conjunto de los estratos «II y II nivel hogar» una misma cronología de primera mitad del siglo II a. C. y asimilarlos funcionalmente al depósito de 1992: encontramos una vez más el hogar/altar (eschára) al fondo del pozo, seguido de la deposición del material votivo.

\section{El relleno del silo 28. Las terracotas con cabeza de Deméter (fig. 18)}

Publicado en $1980^{57}$, el relleno de este silo presentó una vez más un conjunto de materiales datables en la primera mitad del siglo II a. C.: fragmentos residuales de cerámica ática, campaniense A antigua, bicónicos y páteras en gris de la costa catalana, cerámica ibérica pintada en blanco, ánfora ibérica, ungüentarios altos, cerámica a mano y discos cerámicos. Junto a estos materiales se destacó la presencia de un lote de seis terracotas con cabeza de Deméter.

Los contextos de aparición de estas terracotas en Cartago, Sicilia, Cerdeña y las costas ibéricas desde Enserune a Varia y la costa malagueña prueban la variedad de su uso: podian representar a la divinidad en el altar doméstico, acompanar al muerto como ajuar funerario o bien actuar como ofrenda votiva en los santuarios. Su denominación tradicional de thymiateria es confusa ya que tan solo los ejemplares de la favissa de Cartago y algunas de las piezas del depósito del nurage Lugherras presentan restos de fuego en la cazoleta superior, elemento ausente en la mayoría de ejemplares occidentales ${ }^{58}$.

La presencia de estas piezas en Pontós deben corresponder una vez más a una ofrenda votiva, corroborando la ya citada asociación entre estas terracotas y las figuritas femeninas drapeadas evidenciada en el depósito de Camarles.

\footnotetext{
${ }^{55}$ Martín, op.cit. n. 3.

${ }^{\text {st }}$ Martin, op.cit. n. 3, 680.

57 Martín y Llavaneras, op.cit. n. 5 .

${ }^{58}$ Cf. Pena, M.J., Considerazioni sulla diffusione nel Mediterraneo Occidentale dei bruciaperfumi a forma di testa femminile, Atti del II Congr. Int. di Studi Fenici e Punici, III, Roma, 1991, 1109-1118.
} 

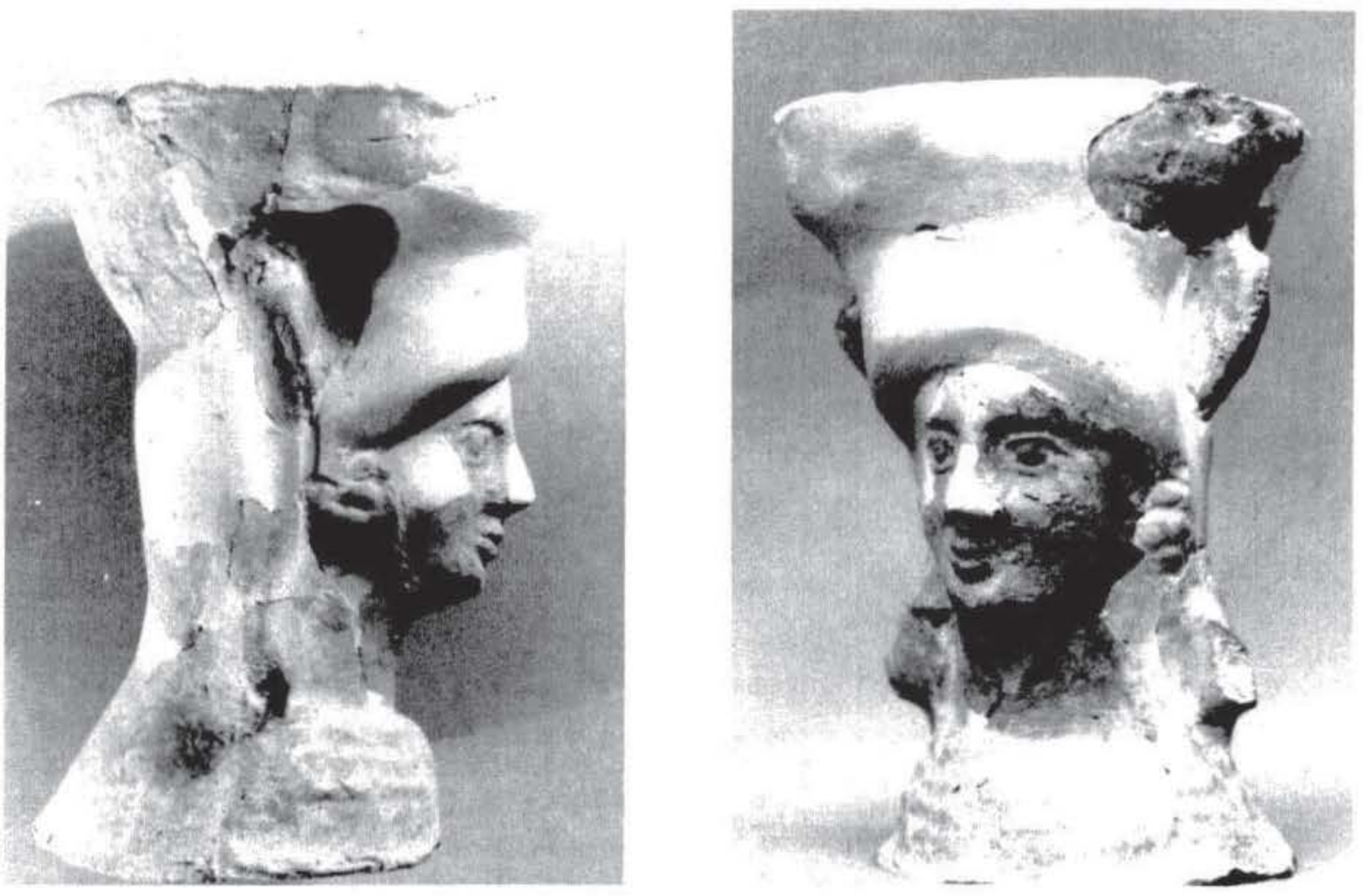

Figura 18. - Terracota de cabeza de Deméter del silo 28.

El ostrakon ibérico del silo 25 (Fig. 19)

Publicado por Martin en 1977, se trata una vez más del relleno de colmatación de un silo. Sobre una plataforma inferior estéril se extiende un nivel homogéneo muy rico en materiales con una Lamb. 23 en barniz negro (Rosas o campaniense A), ánforas grecoitálicas, ánfora púnica centromediterránea, ánfora ibérica, cerámica ibérica de pintura blanca y un amplio conjunto de 295 discos recortados en cerámica. Excepcionalmente, uno de estos discos presentaba un texto ibérico de cuatro lineas ${ }^{50}$. Aunque en este caso las características del depósito parecen mostrar una simple escombrera, la presencia del amplio conjunto de discos incluyendo el ostrakon resulta significativa y el estudio particular de este último lleno de esperanzas si pensamos en inscripciones votivas análogas como las de Bitalemi o Heraclea que mencionaremos más adelante.

\section{Las ofrendas de canidos en el edificio I}

En su informe preliminar, los estudiosos de la fauna ( $S$. Casellas y M. Saña) han subrayado su sorpresa por la abundancia de restos faunisticos de perro sobre el suelo de la sala I (SL 14).

5" ku]lkitibas / alaursu tukein / biurtileis / bilotikerei, (cuarta linea de mano diferente) según la última transcripción de Velaza, J.: Léxico de inscripciones ihéricas, Barcelona, 1991, 185 y passim. E1 texto corresponde a una serie de antropónimos ante lo cual la posibilidad de que se trate de la dedicatoria a una divinidad por parte de un devoto no puede descartarse. 


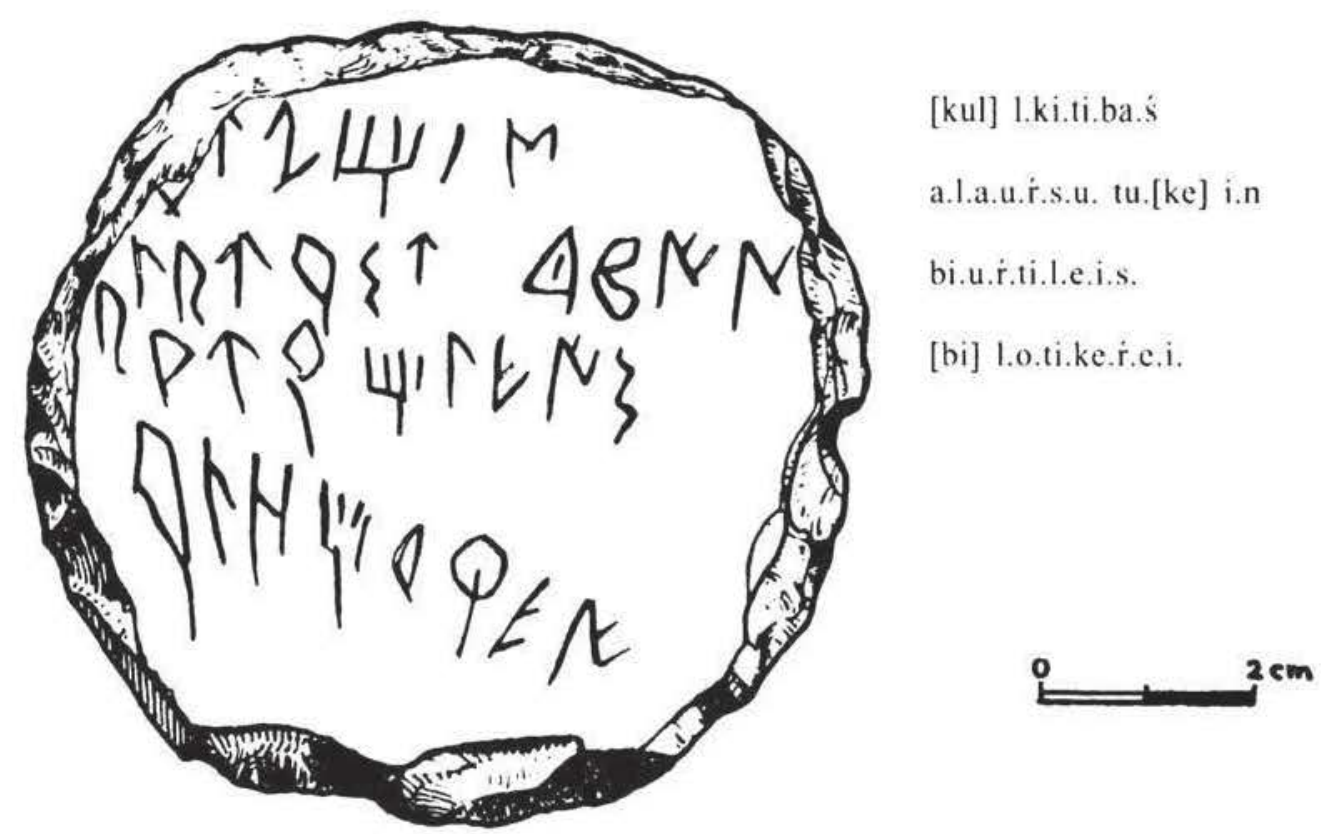

Figura 19.--Ostrakon con texto ibérico aparecido en el silo 25.

Estos restos pertenecen a un mínimo de cinco individuos y en un alto indice se encuentran en conexión anatómica. Unicamente un calcáneo presenta estrias de descuartizamiento.

Esta presencia mayoritaria de cánidos no puede ser casual, aun más si estamos hipotetizando la existencia de un santuario de tipo ctónico por la ofrenda en bóthros del silo 101. Ahora bien ¿qué significado puede tener el sacrificio de cánidos? En este caso, encontramos un interesante paralelo para un ritual semejante en la propia Roma.

Según la tradición mítica, el rey Numa instituiria en Roma las Robigalia, celebradas el 25 de abril. Su culto perduraría durante el Imperio, en relación directa con la fiesta y ludi de Ceres-Deméter (19 de abril). Ovidio nos describe el rito al contemplar casualmente su celebración, en el quinto miliario de la via Claudia, junto al lacus Robigi. Presidida por el sacerdote de Marte (flamen Quirinalis), la procesión desfilaba desde Roma hasta este lugar, donde tras la oración, junto con libaciones de vino y purificación con granos de incienso se inmolaban las entrañas de dos víctimas propiciatorias: una oveja y una perra. Ovidio señala la extrema rareza en el ritual romano del sacrificio de esta última y lo explica por el motivo de la celebración: la diosa Robigo debía evitar que el grano, en su madurez, fuera atacado por el parásito de la roya y éste se manifestaba cíclicamente en relación con la aparición en el firmamento de la constelación del $\operatorname{can}^{60}$. Todavía encontramos en Roma una segunda fiesta arcaica celebrada con idéntico procedimiento y por iguales motivos. Se trata del sacrificium o augurium canarium, celebrado en las afueras de la ciudad, junto a la puerta denominada precisamente catularia (de catula. perra o cachorro). En ella se inmolaba una perra de color rojo para preservar las mieses del ataque de la roya ${ }^{61}$.

${ }^{60}$ Ovidio, Fast., IV, 905 y ss. Cf. Sabatucci, D. 1988: La religione di Roma antica. Dal calendario festivo al ordine cosmico, Milán, 132-138. La roya es un hongo parásito con aspecto de polvo amarillo que ataca la maduración de los cereales.

${ }^{61}$ DA, s.v. Robigo (J.A.Hild). 
Sabemos además que la Deméter helénica ostentaba idénticos poderes a través de diferentes epítetos en que la diosa es recordada como «la que vigila la formación de los granos», "la que defiende el grano de la roya» y en suma "la que hace madurar el grano al calor del sol»" ${ }^{6}$.

La abundancia de perros en el ambiente 1 de Pontós puede por tanto explicarse como la evidencia de las últimas ceremonias celebradas en el santuario. La existencia de este pudridero no debe extrañar a nuestra mentalidad si pensamos en otros casos documentados de áreas sacras donde los restos de los sacrificios quedaban dispersos en torno a los altares ${ }^{63}$. No podemos de momento asegurar si este tipo de sacrificios indicaria la presencia de latinos en las últimas décadas de la vida del santuario o si por el contrario se trata de un tipo similar de ceremonias que en el área grecoindiceta protegiesen la maduración del cereal con ritos análogos ${ }^{n-4}$.

\section{Aproximación al culto e interpretación de un santuario ctónico}

Aunque los orígenes del yacimiento quedan todavía por definir con precisión, éste parece convertirse a partir de un cierto momento (¿siglo IV a. C.?) en un campo de silos organizado en torno a un santuario. Es evidente que ambos factores (silos y santuario) están en directa relación ya que no en vano las divinidades invocadas son precisamente las diosas griegas protectoras de los cereales. Deméter pasa por ser la responsable y divulgadora de la ciencia de la siembra, cosecha y transformación del cereal. Plinio $(\mathrm{HN}, 7,157)$ atribuye a la diosa las artes de moler el grano en el molino, preparar la pasta y cocer el pan. En último termino, Deméter es igualmente la responsable del almacenamiento del cereal (Diod., V,68) y, bajo la invocación de epikleida, su guardiana ${ }^{65}$.

Este culto a las «grandes diosas» se inserta en un contexto religioso ampliamente divulgado por todo el mundo helénico. En Eleusis los solemnes Misterios evolucionarian rápidamente hacia un culto iniciático en busca de la perfección y la inmortalidad ${ }^{\text {th }}$. Pero precediendo esta iniciación existió antes que nada un culto de fertilidad de ciclo anual, protector de las cosechas y la reproducción humana. Atenas instituiría en el siglo $v$ a. C., tras una hambruna, la solemne procesion de la Proerosia a Eleusis y la ofrenda a las "grandes diosas» de las primicias de la recoleccion en nombre de todos los griegos con el fin de obtener «bellas y abundantes cose-

${ }^{\circ 2}$ DA s.v. Ceres, p. 1035, notas 469-474.

${ }_{63}$ En el Heracleion de Thasos los huesos... «portent egalement des traces d'exposition au soleil et de morsures de chiens, laissant penser qu'apres l'execution du sacrifice et la consommation des viandes, les os sont restés a l'air libre avant d'être enterrés", Des Courtils, J. y Pariente, A.: Problèmes topographiques et religieux à l'Heracleion de Thasos, L'espace sacrificiel, op. cit. n. 18, 70. En Bitalemi (Orlandini, infra n. 102, lam.52,2) encontramos in situ encima del fuego/altar la mandibula del cerdo que alli fue asado. En general, los restos oseos que aparecen en los estratos de colmatación o depósitos votivos de santuarios son siempre interpretados como restos de los sacrificios.

${ }^{64}$ Sobre estos sincretismos, pensemos por ejemplo en el paralelismo existente entre las inhumaciones de neonatos en el interior de las casas ibéricas (v. p.e. Cuad. de Prehist. y Arq. Castellonen$s e, 13)$ con los idénticos enterramientos sub grundo que Servio, Ad. Aen, V, 64 describe en la tradición romana.

${ }^{65} \mathrm{Cf}$. $D A$, s.v. Ceres con otras referencias y atributos.

${ }^{66}$ Excelente sintesis de los ritos y divinidades asociadas en $D A$, s.v. mysteria (Ch Lecrivain); v. como estudio clasico Mylonas, G.: Eleusis and the Eleusinian Mysteries, Princeton/London, 1961. 
chas»" ${ }^{67}$. El rito aparece disperso por todo el mundo helénico como patronazgo de los ritos agrarios de siembra y recolección que conocemos bien en el Ática, con una serie de fiestas repartidas a lo largo del año en un ciclo sintetizado por el descenso (káthodos) y ascenso (ánodos) de Core a los infiernos ${ }^{\text {tx }}$.

Sicilia fue sin duda una de las áreas donde el culto a las grandes diosas alcanzó una mayor difusión. El ritual siciliano y magnogreco presenta como variedad la importancia otorgada a Perséfone a través de su theogamia o matrimonio sacro con Hades como simbolo del matrimonio terrenal ${ }^{69}$. Diodoro (XIV,63) describe en Sicilia la celebración anual de dos festivales básicos: un rito de cosecha a fines de la primavera en recuerdo del descenso de Core, raptada por Hades y un rito de otoño en honor a Deméter. En el festival de otoño, celebrado durante 10 dias, se recordaria la reunión de madre e hija en un ritual equivalente a las thesmophória que tendria como fin la preparacion de la simiente para la nueva cosecha.

Desde Sicilia, el culto se extendería en el siglo IV a. C. al mundo cartaginés como purificación obligada tras el saqueo por Himilcón del thesmophórion suburbano del barrio de Akradina en Siracusa durante el sitio de la ciudad en el 396 a. C., impiedad que habría motivado la maldición de las diosas y una epidemia que devastaria el ejército púnico ${ }^{70}$. Como expiación, Cartago incluiría a las diosas en su panteón con culto «a la griega» por parte de sus principales ciudadanos y griegos residentes en la ciudad.

Ya hemos mencionado anteriormente como paralelo para la posible estructura de culto de Pontós los santuarios urbanos de Morgantina dedicados a Deméter y Core. Añadiremos ahora dos nuevos ejemplos para las cuestiones de ritual.

\section{Los ritos oferentes en Bitalemi y Heraclea}

Los depósitos votivos asociados a los santuarios ctónicos son de una extraordinaria riqueza. Tan solo el gran santuario suburbano de la Malophoros en Selinunte ha proporcionado entre otros materiales 12.000 figuritas votivas de diferentes tipos ${ }^{71}$. Sin embargo, como paralelo para los rituales de Pontós contamos con un excelente ejemplo, aunque algo alejado en el tiempo. Se trata del thesmophórion suburbano de Bitalemi, en Gela ${ }^{72}$.

La vida de este santuario suburbano, situado en una colina costera separada de la ciudad de Gela por la desembocadura del río homónimo, comenzó a mediados del siglo VII a. C. como un santuario abierto, sin construcciones, caracterizado simplemente por restos de hogares

${ }^{67}$ Sokolowski, F.: Lois sacrées des cités grecques, París, 1969, num 5: estelas de Eleusis y Atenas con idéntico documento (423-422 a.C.) mencionando la entrega de las primicias de las cosechas a los sacerdotes de Eleusis con llamada de participación a las villas helénicas aliadas y no aliadas.

${ }^{68}$ Estudios fundamentales: Nilsson, M.: Griechische Feste von religioser Bedeutung mit Ausschluss der Attischen, Stutgart, 1906 (reed. 1957); Deubner, L.: Attische Feste, Berlin, 1932.

69 Zuntz, G.: Persephone. Three essays on religion and thought in Magna Grecia, Oxford, 1971; Zancani, P.: La theogamia di Locri Epizefiri, Arch. St. Calabria, 24, 1955, 283-308; Bell, cit. n. 22, 98-103.

70 Diodoro XIV, 54 y ss.

"Gabrici, E.: Il santuario della Malophoros a Selinunte, Mon. Ant. Lincei, 32, 1927, 1 y ss.

72 Ver como trabajo fundamental Orlandini, P.: Lo scavo del thesmophorion di Bitalemi e il culto delle divinità ctonie a Gela, Kokalos, 12, 1966, 8-35, donde se describen la estratigrafia, el tipo de depósitos y los materiales aparecidos. 
de los sacrificios y ágapes rituales junto a la deposición agrupada de objetos directamente sobre la arena de la colina, habitualmente en posición invertida como simbolo de ofrenda ctónica.

Se trata de estatuillas y máscaras de terracota, balsamarios figurados rodios, vasos tardocorintios, copas jonias, enócoes, estamnos y miles de escifos e hidrias de diferentes tamaños. Aparecen además ánforas de vino y aceite clavadas verticalmente en el suelo, objetos de bronce y, ya en el siglo vi a. C., hasta treinta y un depositos de aes rude (lingotes informes de bronce) y aes signatum (la primitiva forma monetal documentada en Lacio y Etruria). Junto a ellos aparecen los cuchillos de hierro utilizados durante los ágapes y ofrendas de herramientas agricolas en hierro: hoces, azadas y rejas de arado.

En la década 550-540 a. C. el santuario fue dotado de pequeños edificios de adobe (naiskoi) a la vez que se regularizó su superficie. Los depósitos asociados a esta fase siguen conteniendo figuras, máscaras, vasos cerámicos, collares de cuentas, etc. Junto al naiskos G 5 aparece un probable depósito fundacional compuesto por un círculo de 100 copas ácromas invertidas y en el centro una figurita femenina acompañada de una enócoe y una copa en posición normal. Un segundo depósito, asociado al naiskos G 7, está formado por un nuevo círculo, formado esta vez por enócoes ácromas invertidas rodeando una estatuilla de tipo rodio, junto a algunas copas y lucernas en posición normal.

El santuario se incendió a mediados del siglo $v$ y fue reconstruido con nuevas construcciones en piedra. Asociados a ellas continúan apareciendo como ofrendas figuritas femeninas alzadas o sedentes, ponderales de telar, muchos de ellos grabados con la inscripción theotimos (digno de la divinidad) y, como documento definitivo, un ostrakon recortado en la base de una tapa de pixide ática con inscripción grafitada en dos lineas: hiara Thesmophóro / ek tâs Dikaiôs skanàs, "sacro a (Deméter) Tesmoforos, de la tienda de Dikaió». Se trataria pues de un thesmophórion suburbano como ya evidenciaban las ofrendas dedicadas a diosas (incluyendo las habituales figuras de Core con antorcha y cerdito), por parte de mujeres (abundancia de hidrias, vaso femenino por excelencia, pesas de telar). Un culto ctónico (ofrendas invertidas o subterráneas), de protección de los campos (ofrendas de herramientas agrícolas).

En Heraclea, un santuario ctónico se situó entre los años 350 y 250 a. C. sobre los restos de un culto arcaico (fin VII-VI a. C.) surgido en torno a una fuente y asimilado a Atenea, Hera y Deméter $^{73}$. En esta segunda fase, el santuario aparece como una serie de ambientes en torno a un patio provisto de un altar en herradura con agujero interior (bothros). Las ofrendas se depositaban en el subsuelo, en ocasiones en anillos cilindricos de terracota como el encontrado en 1964 conteniendo 80 vasos miniaturísticos, protomos de Deméter con antorcha y cerdito y figuritas femeninas enteras o recortadas ${ }^{74}$. Las ofrendas conservadas incluyen fundamentalmente hidrias votivas con dedicatorias a la diosa por parte de los fieles (también sobre láminas de bronce), vasos miniatura destinados tradicionalmente a contener las primicias, pequeñas hoces votivas representando los instrumentos agrícolas, bustos de Deméter y de Artemis Bendis. Junto a estos materiales, Pianu señala en la última fase de vida del santuario depósitos de

${ }^{73}$ Pianu, G.: Il santuario de Demetra a Heraclea de Lucania, Annali delle Fac. di Lettere e Filosofia di Perugia, 26, 1989, 105-137.

${ }^{74}$ Lo Porto, F.: Stipe di culto di Demetra in Heraclea Lucana, Neutsch, B.(dir.): Archäologischen Forschungen in Lukanien, 11 Suppl., a RM, Heidelberg, 181-192. 
hierros sin definir que relaciona con «rituales de manumisión» ligados al paso de Espartaco por la zona ${ }^{\text {? }}$.

\section{EL SANTUARIO COMO SISTEMA DE RELACIÓN}

Los campos de silos situados en el entorno de la marisma altoempordanesa ya habian sido valorados como el testimonio del comercio del cereal ibérico con los puertos comerciales de Emporion y Rhode pero ignorábamos en qué forma se establecía esta relación ${ }^{76}$. Ahora, por primera vez, comenzamos a tener datos objetivos sobre esta cuestión que apuntan, por lo demás, a un fenómeno ampliamente documentado en el mundo colonial mediterráneo: el papel del santuario como mercado neutral.

Ya fuese en los territorios sometidos a una colonización agraria o en los emporia diseminados por las costas, el santuario extaurbano aparece como el centro de intercambio por excelencia. Lógicamente, no todos los santuarios actuaban igual, ya que el espacio sacro urbano y extraurbano, en una teórica fundación colonial griega en Sicilia o Magna Grecia, integraba una gran variedad de cultos complementarios: el área central del asentamiento urbano acogia los cultos «nacionales», protectores de la población, cuya historia se resumía en construcciones, dones y epígrafes. Al mismo tiempo, otros cultos diferentes se dispersaban por el espacio urbano como testimonio de ritos o grupos diversificados. Un segundo grupo de santuarios "periurbanos" se situaban en el contorno de la ciudad, dentro y fuera de los muros, protegiendo simbólicamente el recinto, favoreciendo las ceremonias iniciáticas en el exterior de la ciudad o simplemente actuando como territorio sacro, neutral y mediador. Un tercer grupo de santuarios se dispersaban por el territorio circundante sacralizando puntos significativos (fuentes, vados fluviales, colinas, etc.) actuando como elementos representativos del control y ordenamiento simbólicos del espacio agrario, complemento necesario de su soberanía. En cuarto lugar, otro grupo de santuarios marcarían las fronteras del territorio, ya fuera como elementos desafiantes ante potencias vecinas o bien simplemente como puntos neutrales que favorecieran los contactos entre comunidades" .

El santuario empórico por antonomasia debía ser un santuario suburbano o extraurbano como garantía de neutralidad y la de sus accesos. En último lugar, estos santuarios extraurbanos podian adoptar también un carácter «federal» como centros de reunión de una población todavía no plenamente urbanizada o bien de grupos que se reconocian pertenecientes a una misma etnia (como el Panionion consagrado a Poseidón por las ciudades jonias).

${ }^{75}$ Pianu, op.cit. n.73,137. Ver tambien Greco, E.: Magna Grecia, Guid. Arch. Laterza, Roma-Bari, 1981,140 y ss.

${ }^{76}$ Ruiz de Arbulo, op. cit. n. 8 y 9.

${ }^{77} \mathrm{~V}$. el corto capitulo pero lleno de sugerencias «Cultes et fondations coloniales» en Polignac, $\mathrm{F}$. de: La naissance de la cité grecque, cultes, espaces et societé VIII-VI a.C., París, 1984, 93-125 que establece (p. 95) la siguiente clasificación: santuario monumental del polo urbano, santuario monumental del polo no urbano, junto a santuarios no monumentales periurbanos y extraurbanos. Para la recogida de los datos referentes a Italia contamos posteriormente con el exhaustivo catálogo de Edlund,I.: The Gods and the place. Location and function of sanctuaires in the countryside of Etruria and Magna Grecia (700-400 BC). Estocolmo, 1987. 
Sobre el funcionamiento de estos santuarios, Coarelli ${ }^{7 x}$ ha recordado una cita de Dionisio de Halicarnasso (III, 32) describiendo el santuario lacial de Feronia que resulta un magnifico paralelo para la situación social que intentamos describir en Pontós:

«Había alli un santuario honrado en común por latinos y sabinos, entre los más sacros de los dedicados a la diosa Feronia, que algunos traducen en griego "portadora de flores", otros "amante de las coronas", otros también Perséfone. A este lugar muchos concurrian de las ciudades vecinas en los dias de fiesta para ofrecer votos y sacrificios a la diosa, muchos para comerciar durante la fiesta: mercaderes, artesanos y ciudadanos..."

En Gela, la abundancia de thesmophória en el entorno de la ciudad ha sido interpretado como evidencia de un proceso de mediación cultural entre la población griega e indigena ${ }^{70}$. Una mediación en la que debieron jugar un papel fundamental las mujeres. No en vano las mujeres eran la primera necesidad de las fundaciones coloniales y el instrumento más habitual para establecer alianzas con las poblaciones indigenas ${ }^{\mathrm{x} 0}$. De cualquier forma es todavia pronto, con la información que disponemos, para plantear una utilización del ritual de Pontós más allá de la mera relación comercial.

\section{SANTUARIO Y TERRITORIO}

Hasta ahora, conocíamos unicamente en el entorno de Emporion y Rhode la existencia de un santuario extraurbano todavia no localizado: el Afrodision situado en el extremo de los Pirineos $^{81}$. Se trata sin duda de una marca geográfica destacada, un lugar de descanso y agradecimiento por parte de los marinos que se enfrentaban a los riesgos de las siempre difíciles travesías del golfo Galo o la superación del cabo de Creus ${ }^{82}$.

La posición de Pontós, equidistante de Emporion y Rhode, unida a la independencia política de ambas poleis en los siglos IV y III a. C. nos impide conocer con seguridad el origen "politico" del santuario o su atribución como santuario de frontera. Como ya se expuso en otro trabajo, la chóra emporitana descrita por Estrabón, extendida desde los Pirineos al Bajo Ampurdán fue creada en un momento tardío, ya por influencia de Roma y tras la entrega de Rhode a

${ }^{78}$ Coarelli, F.: I santuari, il fiume, gli empori, Storia di Roma 1. Roma in Italia, ed. Einaudi, Roma, $1988,127-152$.

${ }^{79}$ Polignac, op. cit. n.77 y ss; seguido por Treziny, H., Cité et territoire, quelques problemes, Le territoire de Marseille grecque (Aix 1985), Aix, 1986, 12.

${ }^{80}$ Recordemos como ejemplo de xenia la leyenda de la fundación de Massalia transmitida por Aristóteles y Trogo Pompeyo: la élite de los colonos foceos recién desembarcados es recibida en hospitalidad por el rey local Nannos en el banquete para preparar las bodas de su hija Gyptis. Durante el mismo, ésta ofrece la copa (es decir escoge por marido) al griego Euxeinos lo que facilitaría la instalación de la colonia, v. como estudio más reciente Pralon, D.: La legende de la fondation de Marseille, Marseille Grecque et la Gaule (Marseille 1990), 1992, 51-56. Como tratamiento general del problema v. Van Compernolle, R.: Femmes indigenes et colonisateurs, Modes de Contacts et processus de transformation dans les societes anciennes (Cortona 1981), Pisa-Roma, 1981, 1033-1049.

${ }^{81}$ Estrabón IV,1,3 y IV,1,6; Ptolomeo II,6,19.

${ }^{82}$ Ruiz de Arbulo, J: Rutas marítimas y colonizaciones en la Península Ibérica, una aproximación naútica a algunos problemas, Italica, 18, 1990, 79 y ss. 
Emporion como ciudad conquistada en el 195 a. $C^{\times 3}$. Antes de ese momento, no podemos saber cuál seria la extension de las chórai respectivas, quizás limitadas a las franjas costeras en las inmediaciones de ambos núcleos ya que la marisma marcaba claramente la frontera interior. Desde este punto de vista, Pontós sería un mercado situado en el interior del territorio ibérico, un punto de acumulación de excedentes agricolas conducidos a la costa por los cauces fluviales.

Podriamos restituir el proceso de la siguiente forma: en un momento determinado, ante la necesidad de establecer lazos comerciales regulares y asegurar los suministros de cereal, los griegos de Emporion y/o Rhode habrian introducido, transformado o pactado en un punto concreto del interior indiceta, la existencia de un santuario extraurbano protector de las cosechas. Una casta sacerdotal, cuyas caracteristicas de momento ignoramos, controlaria su funcionamiento. Este santuario se convertiria a lo largo de diversas fiestas anuales en un lugar de reunión general generadora de un gran mercado. Se trataria de un lugar de función económica pero también, y esto es importante recalcarlo, un vehículo de aculturación a partir del comercio y los sincretismos religiosos ${ }^{84}$.

Es probable que el santuario actuase como «sucursal» de otros santuarios análogos situados en Rhode y Emporion, aunque desconocemos casi todo sobre la topografia sacra de ambos yacimientos en epoca prerromana ${ }^{85}$. No puede ser casual que Emporion y Rhode inauguraran sus series monetales de dracmas de plata a fines del siglo IV a. C. con monedas que tomaban como efigie la cabeza de Core tocada con espigas, del más puro estilo helénico en el caso de Rhode e imitando tipos púnicos en el caso emporitano ${ }^{\mathrm{xt}}$. Aun teniendo en cuenta la copia de motivos destacados en la numismática de la época, la elección concreta de esta diosa de forma coetánea en ambos yacimientos resulta para nosotros significativa. Es cierto, sin embargo, que

${ }^{\times 3}$ Ruiz de Arbulo, op. cit. n. 8.

${ }^{*}$ Sobre el papel culturizador del comercio recordemos la bella leyenda relativa a la fuente de Salmacis, cerca de Halicarnaso recogida por Vitrubio $(11,8)$ :

«El hecho es que, cuando Melantes y Arevanias trasladaron alli (Halicarnaso) una colonia de habitantes de Argos y de Trezene expulsaron a sus habitantes cretenses y lelegos. Estos, por su parte, refugiándose en los montes, se reunían y hacian correrías y cometian latrocinios, devastaban el pais y saqueaban cruelmente a aquellos colonos. Al cabo de no sé cuánto tiempo, uno de los habitantes, seducido por la bondad de las aguas y con la esperanza de sacar provecho, instaló junto a la fuente una tienda provista de toda clase de vituallas: esto fue incentivo para atraer aquellos bárbaros, que dieron en acudir a ella primero aisladamente y luego en grupos, celebrando convites o asambleas. Así, poco a poco, abandonaron sus rudas y agrestes costumbres reduciéndose por su propia voluntad a la dulzura y cortesía de los griegos...»

${ }^{\text {xs }}$ Estrabón unicamente menciona que en ambos yacimientos se veneraba a la Artemis efesia. Sobre la topografia de Rhode tan solo conocemos la situación del yacimiento bajo la Ciudadela de Rosas, unos escasos sondeos inéditos y la excavación de parte de un barrio helenístico con talleres de producción cerámica. Recordemos de cualquier forma que en este barrio se producian terracotas con prótomos de Deméter para ser vendidas como ofrendas funerarias o exvotos en un santuario de la diosa, cf. Martin, op. cit. n. 6, fig. 6 .

En Emporion podemos restituir la situación del templo de Artemis acompañada quizas por Apolo en la Palaiapolis como santuario «nacional». Conocemos además la existencia en posición suburbana de un santuario de culto poliado situado bajo el Asklepieion del siglo II a.C. pero de atribución todavía imprecisa.

El culto a Deméter y Core está atestiguado de momento en Emporion unicamente por una terracota de Core con cerdito y cesto aparecida en 1907 en las dunas cercanas al muelle portuario (v. Anuari del IEC, 1908, 560 y fig. 21; García y Bellido, op. cit, n. 15, CLVII, num. 20). 
estas efigies desaparecerian poco después de los tipos monetales, siendo sustituidas por la ninfa Arethusa de tipo siracusano.

La existencia del santuario de Pontós abre una linea de investigaciones prometedora, a la vez que ayuda a entender datos históricos hasta ahora no interpretados. Un buen ejemplo sería la actitud de Catón cuando Livio narra que desembarcado en Emporion en el 195 a. C. «en la época del año en que los hispanos tenian el trigo en las eras" expulsó a los publicanos proveedores con el famoso "la guerra se alimentará a sí misma» ${ }^{* 7}$. Nunca habíamos entendido cómo, rodeado por un ejército de hispanos en rebeldia, Catón podia dedicarse con tanta seguridad a realizar ataques con su caballeria contra unos oppida establecidos a ciertas distancias. La respuesta era en realidad mucho más sencilla: conocida la existencia de Pontós y quizás otros enclaves semejantes en el entorno de la marisma, Catón pudo asegurar sus suministros mediante un rápido golpe de mano.

La vida económica del santuario no se extinguió con la llegada de Catón pero sí con la reforma provincial de la segunda mitad del siglo II a. C. La última fase de ocupación del santuario se sitúa con precisión en todos los contextos en la primera mitad del siglo II a. C., cuando todavía el mundo ibérico indiceta no habia experimentado más transformación que la obligación de pagar el tributo anual a Roma. Sin embargo, las evidencias de transformación que documentamos a fines del siglo II a. C. en el entorno de Emporion, con la aparición de las primeras villae o la construcción de la nueva ciudad emporitana ${ }^{\mathrm{xx}}$ significaron ciertamente la puesta en marcha de una nueva realidad económica y social en la cual Pontós ya no jugaba ningún papel.

\section{Addendum}

Durante el mes de septiembre de 1993 se ha realizado una nueva campaña de excavaciones en el yacimiento que introduce las siguientes novedades:

1.- La excavación en el sondeo 1 ha demostrado que el denominado edificio singular se ha ampliado en estructuras y a la vez se inserta en un barrio edificado a lo largo de una calle de 5 $\mathrm{m}$. de anchura. Dichas estructuras están limitadas entre el margen este del yacimiento (una carena de $14 \mathrm{~m}$. de altura) y la mencionada calle. La fachada que da a ésta está construida en sillería de piedra arenisca en la parte sur y travertínica en la parte norte, donde nuevas habitaciones amplian la planta limitada por los perfiles del sondeo (de $20 \times 25 \mathrm{~m}$.).

Sobre la funcionalidad de los ambientes señalaremos que la estancia 1 , con puerta a la calle, se dibuja como una sala abierta centrada o patio que comunica las estancias $2,3,4$ y 5 situadas a su alrededor, con diferentes fases de uso. En la fase más antigua, la estancia 5 es un depósito rectangular, probablemente de aceite, y la estancia 4, también abierta a la calle, es un

${ }^{86}$ Villaronga, L.: Numismática antigua de Hispania, Barcelona, 1979, núms. 180 y 181. Rhode: anv. cabeza de Core a la izq., leyenda Rhodeton; rev. rosa vista por debajo. Emporion: anv. cabeza de Core a la izq., leyenda Emporiton; rev. caballo parado coronado por una Níke, gráfila de puntos.

${ }^{87}$ Liv. 34, 9, 10-13 (trad. M. Gázquez): «Era aquélla la época del año en que los hispanos tenian el trigo en las eras; y así habiendo prohibido a los suministradores que acaparasen trigo y habiéndoles reexpedido a Roma dijo: «La guerra se alimentará a si misma». Habiendo salido de Ampurias incendia y saquea el campo enemigo y todo lo llena de huidas y terror.»

${ }^{8 \times}$ Casas, J.: L'Olivet d'en Pujol $i$ els Tolegassos. Dos establiments agricoles d'època romana a Vilademat, Girona, 1989; Ruiz de Arbulo, J: Los inicios de la romanización en Occidente: los casos de Emporion y Tarraco, Athenaeum, 79, 1991, 459-490. 
pequeño taller metalúrgico. En la fase de abandono, la estancia 5 funciona como pequeña despensa, impidiendo la erosión conocer el uso de la estancia 4.

Por el sur. la gran estancia 3, donde aparecieron los restos del altar, se ha completado ocupando un espacio de unos $72 \mathrm{~m}^{2}$ con 4 hogares, uno de los cuales es de mayores dimensiones y aparece centrado. Esta estancia comunica con el patio 1, hacia el norte y con los ámbitos 6 y 7 hacia el sur. Una de ellas se caracteriza por la presencia de un horno construido y el hallazgo de mucho material in situ. De momento hemos encontrado un solo nivel de ocupación en esta zona. La estancia 2 que comunica con la 1 por la zona este, funcionaria también en la fase más reciente como un taller metalúrgico.

Cruzando la calle aparece una nueva serie de ámbitos (en gran parte ocultos bajo el perfil), entre los que podemos definir una nueva calle limitada a ambos lados por un almacén de ánforas, precedido de un pórtico y la base de una escalera hecha con losas, y en posición enfrentada una nueva estancia provista de un horno de obra.

2.- La excavación de la estancia 3 ha proporcionado nuevos fragmentos del altar de mármol que permiten ya su restitución completa en altura $(62 \mathrm{cms})$.

3.--El nivel de abandono de todo el sector queda confirmado en la primera mitad del siglo II a. C.

4.-Destaca entre los materiales cerámicos la presencia de ánforas grecoitálicas y púnicas, cerámica de barniz negro de Roses y abundante cerámica ibérica pintada, lisa y a mano. Cabe señalar el hallazgo de objetos metálicos, especialmente hierros, entre ellos tres espadas con vaina, herramientas agrícolas y gran número de clavos. En la estancia 3 han aparecido también cuatro microvasos votivos.

5.-Con los datos disponibles en este sector podemos plantear de momento dos hipótesis funcionales:

a) En la última fase de la vida del yacimiento nos encontramos ante un pequeño oppidum (calle, edificios) en el que uno de los ambientes tuvo un carácter sacro (ignoramos la posición exacta del altar de mármol). El urbanismo de la fase tardia de l'Illa d'en Reixac (Ullastret), actualmente en excavación, es muy semejante a lo encontrado en Pontós.

b) Se trata de un santuario, entendido como una aglomeración de edificios en los que coexisten las funciones de residencia, almacenaje y transformación de productos. Recordemos que en los citados "santuarios de patio» de Morgantina o en sus inmediaciones también se sitúan actividades de torrefacción de cereales y producción de aceite (Allen, H. L., 1980: 1 luoghi sacri di Morgantina, Il tempio Greco in Sicilia. Architettura e culti, (Siracusa 1976), Cronache d'Archeologia, 16, Catania, 132-139, espec. 137).

En ambos casos, el campo de silos perimetral prueba que el yacimiento actuaba como un punto de concentración y comercio de excedentes agrarios. 